College of William \& Mary Law School William \& Mary Law School Scholarship Repository

2019

Justice on the Line: Prosecutorial Screening Before Arrest

Adam M. Gershowitz

William \& Mary Law School, amgershowitz@wm.edu 


\section{JUSTICE ON THE LINE: PROSECUTORIAL SCREENING BEFORE ARREST}

Adam M. Gershowitz*

Police make more than eleven million arrests every year. Yet prosecutors dismiss about $25 \%$ of criminal charges with no conviction being entered. Needless arrests are therefore clogging the criminal justice system and harming criminal defendants. For instance, Freddie Gray was fatally injured in police custody after being arrested for possession of a switchblade knife. Prosecutors later announced, however, that they did not believe the knife was actually illegal. If prosecutors had to approve warrantless arrests before police could take suspects into custody, Freddie Gray would still be alive. Yet prosecutors' offices almost never dictate who the police should or should not arrest. Based on interviews with forty prosecutors' offices across the country, this Article describes how police-not prosecutors - call the shots about who is input into the criminal justice system.

This Article makes a counter-intuitive argument: we should be giving prosecutors more power so they can better protect innocent defendants. Prosecutors should be responsible for approving or rejecting all warrantless arrests. Early prosecutorial case screening will benefit individuals by preventing unnecessary arrests, which in turn will reduce embarrassing mug shots, unnecessary bail, loss of employment due to pretrial incarceration, and wrongful convictions. Avoiding unnecessary arrests will also reduce jail overcrowding and reduce the burden on judges, clerks, prosecutors, public defenders, and even the police. At present, prosecutorial screening of arrests has been implemented in only a handful of jurisdictions. Prosecutorial prescreening can and should be dramatically expanded across the country to improve the efficiency of the criminal justice system and prevent myriad harms to criminal suspects.

* Associate Dean for Research and Faculty Development and Professor of Law, William \& Mary Law School. I am grateful to the dozens of prosecutors who provided information about their offices. Many thanks also to Jeff Bellin, Rachel Harmon, Ron Wright, and participants at the Neighborhood Criminal Justice Roundtable for helpful comments. Fred Dingledy and Elizabeth Lester provided excellent research assistance. 


\section{TABLE OF CONTENTS}

I. INTRODUCTION

II. Most Prosecutor Offices Have Minimal Involvement in PreSCREENING WARRANTLESS ARRESTS BY THE POLICE

A. Minimal Constitutional Restrictions on Arrests, and

Delayed Review by Prosecutors ......

B. The Prosecutor's Role in Warrantless Arrests: Mostly Minimal,

But with Variations and a Few Exceptions.

1. Counties with No Prosecutor Hotline and Very Limited Prosecutorial Role in Warrantless Arrests......

2. Counties with a Dedicated Prosecutor Hotline for

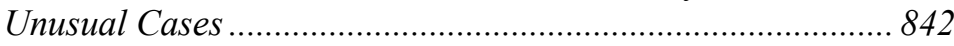

3. Counties with More Frequent Police-Prosecutor

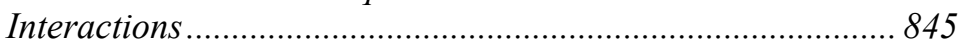

C. The Reasons for Limited Prosecutorial Involvement

Prior to Arrest 848

D. Problems with Limited Prosecutorial Oversight of Police

Decisions to Make Warrantless Arrests.

1. Evidence Collection and Trial Problems for Prosecutors Down the Road

2. Harm to Arrestees Caused by Lack of Prosecutorial Involvement 851

a. Unnecessary Arrests: Police File Charges That Prosecutors Would Not Have Brought 851

b. Arrest Reports and Mug Shots: The Internet Remembers 854

c. Bail Costs Money, and Inability to Post Bail Leads to Job Loss 855

d. Wrongful Guilty Pleas, Lost Wages, Anxiety, and Collateral Costs of Unnecessary Arrests........................ 856

3. Burdening Other Criminal Justice Actors.... 857

III. The HARris COUNTY APPROACH: Prosecutorial SCREENING BEFORE ALL WARRANTLESS ARRESTS 859

A. The Structure of the Harris County Intake Process ........................... 859

B. Cost and Efficiency Savings Under the Harris County Model .......... 861

C. Replicating the Harris County Approach in El Paso and

Montgomery Counties... 866

1. El Paso Recognized the Cost and Efficiency Savings Two

Decades Ago..... 866

2. Montgomery County Adopted a Similar System a

Decade Ago... 868

IV. Expanding Prosecutorial PReScreening of Warrantless ARRESTS TO OTHER COUNTIES . 869 


\section{INTRODUCTION}

The American criminal justice system is clogged and overflowing. ${ }^{1}$ Each year, police ${ }^{2}$ arrest more than 11 million individuals. ${ }^{3}$ Yet prosecutors ultimately dismiss about $25 \%$ of criminal charges with no conviction being entered. ${ }^{4}$ Those numbers tell us there are inputs needlessly clogging the criminal justice system. Jails are holding pretrial detainees who will not end up being prosecuted. Prosecutors are dealing with cases they will ultimately dismiss. Public defenders are overextended in part because of cases that never should have been on their plate in the first place. And, of course, suspects are suffering through needless pretrial incarceration. All of this suggests the criminal justice system should do a better job screening which cases are input into the system in the first place.

Police make the arrests and prosecutors only enter the picture later-days or even weeks later in some counties. ${ }^{5}$ But what if it were feasible for prosecutors to screen cases at a much earlier stage-prior to arrest? What if some of the $25 \%$ of ultimately dismissed cases were never input into the system in the first place? And what if some of the overcharged cases - for instance, aggravated assault felonies that should have been charged as simple assault misdemeanors - could be charged at the correct level in the first place? After interviewing prosecutors in forty different offices around the country, I was told multiple times that prosecutorial screening at the moment of a warrantless arrest would be "impossible." Yet there is at least one large jurisdiction where prosecutors - not the policeare calling the shots about who is arrested without a warrant.

In Harris County, Texas (home to Houston) prosecutors screen cases prior to arrest and thus are able to weed out weak cases before they begin to clog the system and take up criminal justice resources. ${ }^{6}$ Every police officer in Harris

1. As scholars have repeatedly observed, there are more than 2.2 million people in prisons and jails, with many serving incredibly long sentences. See, e.g., Michael Tonry, Sentencing Fragments: Penal Reform IN AMERICA 1975-2025 10 (2016). Although this Article focuses on the moment of arrest, I do not mean to suggest that sentence length has not contributed to mass imprisonment in the United States. One scholar, however, has boldly asserted that sentence length is not a primary driver of the rise of mass incarceration. See JOHN F. Pfaff, Locked In: The True Causes of Mass InCARCERATION—AND How to ACHIEVE Real Reform 5177 (2017). For a persuasive argument that Professor Pfaff is wrong, see Jeffrey Bellin, Reassessing Prosecutorial Power Through the Lens of Mass Incarceration, 116 Mich. L. Rev. 835 (2018).

2. Law enforcement officers have many names - for example, sheriffs, constables, and peace officersbut for ease of exposition, I refer to all of them in this Article as "police."

3. See Crime in the United States 2013, FBI: UCR, https://www.fbi.gov/about-us/cjis/ucr/crime-in-theu.s/2013/crime-in-the-u.s.-2013/persons-arrested/persons-arrested (last visited Mar. 28, 2019).

4. See Brian A. Reaves, U.S. Dep't of Justice: Bureau of Justice Statistics, Felony Defendants in LARGe URBAn Counties, 2009-Statistical TABLES, tbl. 21 (2013). The percentage surely rises when misdemeanor cases are included. And some offices have much higher rates. See Bellin, supra note 1, at 846; Ronald Wright \& Marc Miller, The Screening/Bargaining Tradeoff, 55 STAN. L. REV. 29, $72-74$ (2002).

5. Paul Heaton et al., The Downstream Consequences of Misdemeanor Pretrial Detention, 69 STAN. L. REV. 711, 721 (2017).

6. See Interview with Jim Leitner, Bureau Chief of the Grand Jury Intake Division, Harris County, at the Harris County District Attorney's Office (June 5, 2017) [hereinafter Leitner Interview]. 
County must call into an intake hotline and receive prosecutorial approval for every warrantless arrest before taking a suspect to jail. ${ }^{7}$ Prosecutors have the option to reject the charges or to insist charges in weak cases be downgraded from felonies to misdemeanors prior to jail bookings. ${ }^{8}$ Because the vast majority of arrests are warrantless, these intake prosecutors are conducting an initial review of an enormous portion of the criminal justice docket. They are therefore in a position to prevent clogs before the system swallows weak cases.

Unfortunately, Harris County is nearly unique. While two other Texas counties have adopted a version of the Harris County approach, interviews with nearly forty other large and medium-sized prosecutors' offices across the nation show that prosecutors almost never screen warrantless arrests. ${ }^{9}$ While many prosecutors' offices operate hotlines so that police can call with questions, the police still run the show. ${ }^{10}$ Across most of the United States, police simply arrest suspects and process them into the system, with weak cases languishing until prosecutors eventually dismiss or downgrade them days, weeks, or even months later. $^{11}$

The traditional process in which police make threshold decisions is problematic for the prosecutors who must handle the cases as well as the sheriffs running the overcrowded jails, the clerks and judges handling overflowing dockets, and the public defenders who are already drowning in far too many cases. ${ }^{12}$ And the system is even worse for the arrestees who must spend unnecessary time in jail, use what little savings they have to post bail, and possibly lose their jobs while being detained. ${ }^{13}$ Moreover, some arrestees suffer further because their warrantless arrests are reported to immigration authorities, public housing units, and employers, even if the charges are ultimately dropped. ${ }^{14}$ And, of course, some arrestees plead guilty simply to get out of jail before prosecutors and defense attorneys have an opportunity to discover the fatal flaws in their cases. ${ }^{15}$

This Article proceeds in three parts. Part II reports how forty prosecutors' offices around the country interact with police at the moment of warrantless arrests. Part II describes how many prosecutors' offices have optional hotlines for police to call with questions. Yet, because calls are not required, contact between police and prosecutors at the point of arrest is relatively rare. Part II then explains how the lack of prosecutorial screening allows weak cases to languish for days or weeks before a prosecutor decides to dismiss the case or downgrade felony charges to misdemeanor charges. Part II also explains how the delay in dropping or reducing charges wastes criminal justice resources and deeply harms individuals who would otherwise not have been incarcerated. Part III then describes the

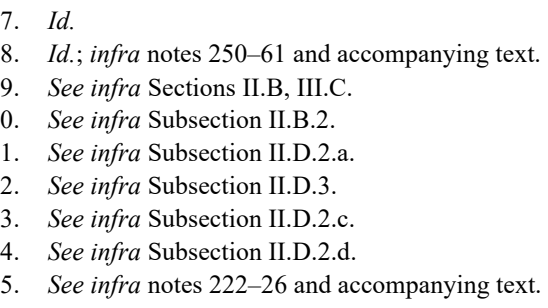


rigorous screening process in place in Harris County, Texas. Part III explains how a prosecutor reviews every case before police make a warrantless arrest and take a suspect to jail. Finally, Part IV makes the case that other medium-sized and large jurisdictions should follow the Harris County model and screen warrantless arrests in real time. Part IV also explores whether it would be feasible for states to fund centralized screening offices to be shared by smaller counties.

\section{Most Prosecutor Offices Have Minimal Involvement in Pre- SCREENING WARRANTLESS ARRESTS BY THE POLICE}

Police officers have enormous power in the United States criminal justice system. Legislatures have criminalized a huge number of offenses ${ }^{16}$ and have authorized police to make arrests in most cases, even low-level misdemeanors. ${ }^{17}$ This Part explores (A) the relatively limited restrictions the Supreme Court has imposed on warrantless arrests; (B) the fairly modest role of most prosecutors' offices in working with police to determine which warrantless arrests to make; (C) the reasons why prosecutors' offices do not exert more influence in police decisions to make warrantless arrests; and (D) the problems caused by having limited prosecutorial oversight of warrantless arrests by the police.

\section{A. Minimal Constitutional Restrictions on Arrests, and Delayed Review by Prosecutors}

The Supreme Court has lightly regulated police authority to arrest suspects. ${ }^{18}$ And the Court has imposed no real burden on prosecutors to quickly screen those arrests.

Of course, the Court has long required that police have a warrant to arrest a suspect in her home. ${ }^{19}$ With the exception of a recent decision expanding the exigent circumstances doctrine to allow police to create their own exigency, ${ }^{20}$ the Court has held a firm and rigorous line at the entrance to the home. ${ }^{21}$

Outside of the home is a far different story, however. Courts have long authorized police to arrest without a warrant outside of the home. ${ }^{22}$ So long as the officers have probable cause, they can effectuate an arrest without first having to

16. See William J. Stuntz, The Pathological Politics of Criminal Law, 100 MiCH. L. REV. 505, 507 (2001).

17. See Stephen E. Henderson, “Move On” Orders as Fourth Amendment Seizures, 2008 BYU L. REV. 1, $36-37$.

18. See Rachel A. Harmon, Why Arrest?, 115 MicH. L. REV. 307, 321 (2016).

19. See Payton v. New York, 445 U.S. 573, 576 (1980).

20. See Kentucky v. King, 563 U.S. 452, 462 (2011).

21. See Payton, 445 U.S. at 576.

22. See United States v. Watson, 423 U.S. 411, 414-17 (1976). 
check with a judge or a prosecutor. ${ }^{23}$ And, of course, the vast majority of arrests are made without a warrant. ${ }^{24}$

Only after a warrantless arrest does the role of the judge formally apply. ${ }^{25}$ In County of Riverside v. McLaughlin, the Court required that judges review warrantless arrests within forty-eight hours. ${ }^{26}$ The County of Riverside decision officially puts the burden on judges. ${ }^{27}$ In many jurisdictions, however, prosecutors appear at the probable cause hearing to make the case that probable cause exists for the arrest. $^{28}$

Some jurisdictions are more rigorous. In about ten states, statutes require a probable cause determination within twenty-four hours. ${ }^{29}$ But additional state statutory protection appears to be the exception rather than the rule. ${ }^{30}$ In most of the country, the only hard law governing arrests is the Supreme Court's mandate that there be a probable cause hearing forty-eight hours after arrest. Unless the prosecutor's office has an internal policy to insert itself earlier, that means that it is police - not prosecutors - who are deciding initial inputs in the criminal justice system. ${ }^{31}$ Put differently, if the prosecutor does not voluntarily step in earlier than required by the Supreme Court, it is police officers - not prosecutors- that decide who spends the weekend in jail. As described in Section II.C below, unfettered police authority can cause a host of problems. Before proceeding to those problems though, it is important to have a sense of how police and prosecutors interact prior to arrests being made. Section II.B below reviews the policies and practices of more than three-dozen prosecutors' offices in working with the police on warrantless arrests.

23. At common law, for an officer to make a warrantless arrest on a misdemeanor, the crime had to occur "in view" of the officer. See Watson, 423 U.S. at 417-18. Modern decisions, however, have held that the Fourth Amendment allows such arrests even if not "in view" of the officer. See, e.g., Woods v. City of Chicago, 234 F.3d 979, 992 (7th Cir. 2000) ("The Supreme Court has never held that a police officer violates the Fourth Amendment merely by arresting someone without a warrant for a misdemeanor offense which did not occur in the officer's presence and/or did not involve a breach of the peace.”).

24. See Harmon, supra note 18 , at 324 .

25. See id.

26. 500 U.S. 44, 55-58 (1991). The Court left some wiggle room by explaining that review within fortyeight hours could still be unconstitutional if the probable cause determination was delayed unreasonably. $I d$. at 56-57. The Court also recognized that a valid hearing could occur more than forty-eight hours after arrest so long as the State could prove a bona fide emergency. Id. at 57.

27. See id. at 56-57.

28. Of the forty prosecutor's offices that responded to my request for information, a few indicated that its prosecutors do not appear at the probable cause hearing. See infra notes 89, 144, 157, 240 and accompanying text.

29. See Ala. Code $§ 15-13-190$ (1975); Del. Code AnN. tit. 11, § 1909 (2010); Mo. AnN. STAT. $\$ 544.170$ (West 2019); N.H. ReV. STAT. ANN. § 594:20 (2017); S.C. CODE ANN. §22-5-510 (2015); TEX. CODE CRIM. Proc. ANN. art. 17.033(a) (West 2019); ArIz. R. Crim. P. 4.1; Fla. R. CRIM. P. 3.130; MD. R. CRIM. P. 4-212; MASS. R. CRIM P. 3.1; see also MINN. R. CRIM. P. 4.02 (setting period at thirty-six hours).

30. Most state statutes typically quote language from the County of Riverside decision and state that probable cause hearings must occur without "unnecessary delay." See, e.g., KAN. STAT. ANN. § 22-2901 (West 2019).

31. See, e.g., Issa Kohler-Hausmann, Managerial Justice and Mass Misdemeanors, 66 STAN. L. REV. 611, 636 \& n.60 (2014) (studying New York City and explaining that although the district attorney's office can change charges before arraignment, it is the police who determine initial charges). 


\section{B. The Prosecutor's Role in Warrantless Arrests: Mostly Minimal, But with Variations and a Few Exceptions}

Prosecutors typically participate in probable cause hearings within fortyeight hours of arrest. ${ }^{32}$ But do prosecutors become involved earlier, even though they are not constitutionally required to do so? In particular, I sought to determine whether offices assign prosecutors to prescreen or otherwise help police with warrantless arrests so weak cases are not brought into the criminal justice system in the first place. ${ }^{33}$ In order to answer this question, I contacted prosecutors in the 100 largest counties in the United States as well as a few smaller jurisdictions. ${ }^{34}$ Many offices declined to respond, but I was able to speak or correspond with prosecutors from forty offices. ${ }^{35}$

While there certainly is not uniformity ${ }^{36}$ the results of my study clearly indicate that most prosecutors' offices do not have significant interaction with police at the time of warrantless arrests. ${ }^{37}$ Numerous offices have either a hotline telephone number or a rotating prosecutor on call to answer questions from police. ${ }^{38}$ In most jurisdictions, however, phone calls from the police are the exception, not the rule. ${ }^{39}$ And when police do call, they are mostly seeking legal guidance for what the officers think are the difficult cases. ${ }^{40}$ In almost all jurisdictions, police do not need to receive permission from prosecutors in order to effectuate a warrantless arrest and lock up a suspect. ${ }^{41}$ In the subsections below, I detail the different approaches prosecutors use to provide guidance to the police.

1. Counties with No Prosecutor Hotline and Very Limited Prosecutorial Role in Warrantless Arrests

In some jurisdictions, prosecutors' offices have no substantial role in advising the police whether to make warrantless arrests. ${ }^{42}$ For instance, a veteran prosecutor in Los Angeles explained:

32. Wright \& Miller, supra note 4 , at 32 n.9.

33. The leading work on prosecutorial screening considers screening at a later stage. See id.

34. Ron Wright and Kay Levine have thoughtfully observed that research on prosecutors' offices focuses too heavily on large jurisdictions. See Ronald F. Wright \& Kay L. Levine, Place Matters in Prosecution Research, 14 OHIO ST. J. CRIM. L. 675, 679 (2017).

35. I divided the jurisdictions equally with a research assistant. We first called each office in an effort to speak with a prosecutor or public information officer who could answer the questions. We then followed up by email with an identical set of questions for each office.

36. See Ronald F. Wright et al., The Many Faces of Prosecution, 1 StAn. J. CRIM. L. \& POL'Y 27, 28 (2014) (cautioning against reaching broad conclusions about all prosecutors based on data points from a few offices).

37. See discussion infra Subsection II.B.1.

38. See discussion infra Subsection II.B.2.

39. See discussion infra Subsection II.B.2.

40. See discussion infra Subsection II.B.2.

41. See discussion infra Subsection II.B.2.

42. See infra notes $43-52$ and accompanying text. 
[T] he nature of law enforcement in a jurisdiction of our size is such that an officer stopping midstream to seek advice on making a warrantless arrest is highly unlikely. Most warrantless arrests occur when the officer sees the violation occur (such as driving under the influence), or discovers it during lawful activity (narcotics found during a lawful search of a parolee, for example) .... Such situations do not call for prior consultation with the prosecutor. ${ }^{43}$

This prosecutor further noted that "in my 2 years as a police officer I never consulted a prosecutor before making an arrest; in my 31 years as a prosecutor, I don't recall ever having been asked for such advice before an arrest was made." 44

The situation in some other California counties is similar. In Fresno County, California, the District Attorney's Office does not maintain a hotline, and police only call individual prosecutors for advice on arrests "very very rarely" and "only in serious cases." ${ }^{45}$ Fresno County prosecutors do not become involved in cases until thirty-six to forty-eight hours after arrest. ${ }^{46}$ Similarly, in San Joaquin County, California, a prosecutor explained that we "do not involve ourselves in warrantless arrests" although there "may be an unusual case where an officer will call an intake/charging deputy during business hours." ${ }^{, 47}$ Prosecutors in San Joaquin typically review the police report the day following the arrest. ${ }^{48}$ In Kern County, California (home to Bakersfield), the District Attorney's Office does not have a hotline and only reviews cases after they are formally submitted to the office, which is within two days for warrantless arrestees in custody and up to a few weeks later for those no longer in custody. ${ }^{49}$ Finally, in Contra Costa, California, prosecutors "generally do not get involved until the case is brought in for filing." 50 When the suspect has been booked and released (as happens, for example, in a typical drunk driving case), the prosecutor's office "usually won't become involved in the case until months later." 51 If the suspect is still in custody, prosecutors will typically first look at the case thirty-six to forty-eight hours after arrest. ${ }^{52}$

Some large prosecutors' offices in other states likewise do not offer much advice to police at the moment of arrest. ${ }^{53}$ For example, a spokesman for the Philadelphia County prosecutor's office in Pennsylvania explained that "we do

43. See E-mail from Devallis Rutledge, Special Counsel to the Dist. Attorney, L.A. Cty. Dist. Attorney's Office, to author (May 17, 2017) (on file with author).

44. Id. Los Angeles County does have a twenty-four hour call-in line for police to speak with a prosecutor, but it is primarily for "help obtaining search warrants, wiretaps, or other court orders." Id.

45. E-mail from Steve E. Wright, Assistant Dist. Attorney, Fresno Cty., to author (May 24, 2017) (on file with author).

46. See id.

47. See E-mail from Robert Himelblau, Supervising Deputy Dist. Attorney, San Joaquin Cty., to Elizabeth Lester (June 15, 2017, 5:37 PM) (on file with author).

48. See id.

49. See E-mail from Mark Pafford, Chief Deputy Dist. Attorney, Kern Cty., to Elizabeth Lester (June 19, 2017, 12:59 PM) (on file with author).

50. See E-mail from Brian Feinberg, Deputy Dist. Attorney, to author (June 16, 2017) (on file with author).

51. $I d$.

52. See id.

53. See infra notes 54-60 and accompanying text. 
not provide advice about whether or not to arrest a suspect .... The police determine whether or not to effectuate an arrest." ${ }^{154}$ Thereafter, a case moves to the charging unit of the prosecutor's office, which typically decides within eleven hours whether to file charges. ${ }^{55}$

The Suffolk County District Attorney's Office in New York operates similarly. Suffolk County does not have a hotline, and prosecutors do not talk with police in run-of-the-mill cases, though they do sometimes answer questions when police call in specialized cases such as child abuse. ${ }^{56}$ Like Philadelphia, though, Suffolk County prosecutors review cases fairly quickly after arrest, typically within twelve- to twenty-four hours of a warrantless arrest. ${ }^{57}$ Similarly, the San Francisco County District Attorney's Office in California does not have a hotline for police to call about warrantless arrests, though police can call individual departments in the office to ask questions about cases. ${ }^{58}$ The San Francisco office stressed that even when police do reach out with questions, prosecutors do not provide conclusions for the police about whether or not there is probable cause to make an arrest. ${ }^{59}$ In the ordinary case, prosecutors only become involved in the case about a day after arrest. ${ }^{60}$

In Pima County, Arizona prosecutors handle felonies while the Tucson City Attorney's Office handles most misdemeanors. ${ }^{61}$ Neither jurisdiction has a hotline for police to talk with prosecutors prior to arrest. ${ }^{62}$ For felony cases, a Pima County prosecutor reviews the case at the probable cause hearing within twelve hours of arrest. ${ }^{63}$ In misdemeanor cases, judges conduct probable cause reviews in the evenings, but prosecutors are only on staff Monday through Friday from 9 a.m. to 5 p.m. ${ }^{64}$ If a defendant is arrested on misdemeanor charges during the weekend, a prosecutor will not review the case until Monday morning.

Some medium-sized counties also reported that contact between police and prosecutors at the time of arrest is fairly rare. ${ }^{65}$ For example, in El Paso County, Colorado (home to Colorado Springs), the prosecutor's office does not maintain a dedicated hotline for police to consult with prosecutors and calls from police

54. E-mail from Cameron L. Kline, Commc'ns Dir. \& Spokesperson, Phila. Dist. Attorney’s Office, to author (May 18, 2017) (on file with author).

55. See id.

56. See Interview with Michael J. Miller, Chief of Appellate Bureau, Suffolk Cty. Dist. Attorney's Office (June 20, 2017) [hereinafter Miller Interview].

57. See id.

58. See E-mail from Nikesh Patel, S.F. Cty. Dist. Attorney's Office, to Elizabeth Lester (July 7, 2017) (on file with author).

59. See id.

60. See id.

61. See E-mail from Amelia Cramer, Chief Deputy Pima Cty. Attorney, to author (June 2, 2017, 11:03 AM) (on file with author).

62. See id.; Interview with M.J. Raciti, Principal Assistant Prosecuting City Attorney (June 2, 2017) [hereinafter Raciti Interview].

63. See E-mail from Amelia Cramer, supra note 61. Thereafter, prosecutors will not review the case again for up to eight days. See id.

64. See Raciti Interview, supra note 62

65. See infra notes 66-71 and accompanying text. 
occur only on "rare occasions." ${ }^{96}$ Likewise, in Salt Lake County, Utah, prosecutors do not maintain a hotline and speak with police about warrantless arrests only "occasionally." 67

In Montgomery County, Maryland, the State's Attorney's Office does not maintain a hotline, though police have some prosecutors' cell phone numbers and are instructed to call the Deputy State's Attorney with questions. ${ }^{68}$ Nevertheless, the Deputy State's Attorney explained that calls from police to prosecutors are "infrequent" and mostly occur in homicides, cases where juveniles will be charged as adults, or cases likely to generate news coverage. ${ }^{69}$ The Deputy State's Attorney explained that the Montgomery County office would like to interact more with police at the time of warrantless arrests because the "earlier we can weigh in on a case" the better. ${ }^{70}$ Unfortunately, the Montgomery County, Maryland State's Attorney's Office believes the cost of hiring prosecutors to communicate with police at the time of arrest would be prohibitively expensive. ${ }^{71}$

In sum, in a number of large and medium-sized counties across the United States, police have total discretion to make warrantless arrests and seek virtually no feedback from prosecutors in doing so.

\section{Counties with a Dedicated Prosecutor Hotline for Unusual Cases}

In a considerable number of counties, the prosecutor's office has a system set up for police to contact prosecutors if they want guidance prior to making warrantless arrests. ${ }^{72}$ Some jurisdictions maintain a dedicated hotline for police to call. ${ }^{73}$ In other jurisdictions, prosecutors take turns giving out their cell phone number to the police and are essentially "on call" the way an obstetrician is for delivering babies. ${ }^{74}$ In all of these jurisdictions, phone calls from the police about whether to make a warrantless arrest seem to be the exception and not the rule. ${ }^{75}$ The police are not obligated to call prosecutors for guidance and only do so when the officers think the case is complicated. ${ }^{76}$

For instance, in Wayne County (Detroit), Michigan, there is a rotating list of prosecutors who are available for the police to contact about legal issues at any time afterhours, seven days a week. ${ }^{77}$ There is no requirement for police to

66. See E-mail from Lee Richards, Pub. Info. Officer, El Paso Cty. Dist. Attorney’s Office, to Elizabeth Lester (June 15, 2017, 6:07 PM) (on file with author).

67. E-mail from Blake Nakaumura, Salt Lake Cty. Dist. Attorney's Office, to author (June 15, 2017) (on file with author).

68. See Interview with Peter Feeney, Deputy State's Attorney, Montgomery Cty. Dist. Attorney's Office (July 10, 2017) [hereinafter Feeney Interview].

69. $I d$.

70. $I d$.

71. See id.

72. See infra notes 77-82 and accompanying text.

73. See infra notes $83-88$ and accompanying text.

74. See infra notes 77-79 and accompanying text.

75. See infra notes $78-88$ and accompanying text.

76. See infra notes $78-88$ and accompanying text.

77. E-mail from Maria Miller, Wayne Cty. Assistant Prosecutor, to author (May 16, 2017) (on file with author). 
call prosecutors, however, and in fact, they only seek input from prosecutors on search warrants and other legal matters in a limited set of cases. ${ }^{78}$ In Franklin County (Columbus), Ohio, there is no hotline for police to call, although prosecutors in certain divisions give out their cell phone numbers to law enforcement. ${ }^{79}$ According to a spokesperson in Columbus, "in run-of-the mill type cases it is atypical for the prosecutors to get calls from the police, however in our big cases, cold cases, sex abuse cases, white collar crime cases, and gang cases, our prosecutors do get calls from the police." 80

Similarly, a prosecutor in Allegheny County, Pennsylvania (home to Pittsburgh) explained that "we have a monthly on call list that goes out to law enforcement .... Our prosecutors will often receive calls following an on view arrest if the arresting officer wants some guidance on exactly what to charge once the suspect is in custody." ${ }^{81}$ While the Allegheny prosecutor's office makes itself available to the police to answer complicated legal questions, it "would never require a police officer to call us before making an on view arrest." 82

Numerous jurisdictions that staff prosecutor hotlines report that calls are rare. ${ }^{83}$ Consider the similar approach in three Texas counties. In Fort Bend County (in the suburbs of Houston), prosecutors are available twenty-four hours a day, but the office reports receiving calls only "a few times weekly." ${ }^{84}$ Bexar County, Texas (which is home to San Antonio) operates similarly. ${ }^{85}$ The office does not have a hotline, but it does staff a prosecutor twenty-four hours a day to be available to answer questions from police. ${ }^{86}$ The police, however, tend to call prosecutors only in cases with unusual facts or tricky legal issues; in run-of-themill cases police do not consult prosecutors. ${ }^{87}$ In Denton County, Texas, prosecutors have a dedicated phone line, but calls from police come only in unusual cases and are "fairly rare." ${ }^{\prime 8}$ Moreover, in Denton County—which has over 600,000 people - prosecutors "do not attend any probable cause hearings and do not have anything to do with the [warrantless arrest] case[s] at all until weeks/months later." 89

\footnotetext{
78. Id.

79. See E-mail from Christy C. McCreary, Pub. Info. Officer, Franklin Cty. Dist. Attorney's Office, to author (May 31, 2017) (on file with author).

80. Id. (June 1, 2017) (on file with author).

81. E-mail from Mike Manko, Allegheny Cty. Dist. Attorney's Office, to author (May 16, 2017) (on file with author).

82. $I d$.

83. E-mail from Wesley Wittig, Exec. Assistant Dist. Attorney, Fort Bend Cty., to author (May 19, 2017) (on file with author).

84. Id.

85. See E-mail from Jennifer Saucedo Rodriguez, Bexar Cty. Dist. Attorney's Office, to author (June 8, 2017) (on file with author)

86. See id.

87. See id.

88. E-mail from Jamie Beck, First Assistant Dist. Attorney, to Elizabeth Lester (June 8, 2017) (on file with author)

89. Id.
} 
Prosecutors' offices in other parts of the country also reported that calls from police are infrequent. ${ }^{90}$ For example, in Ventura County, California, if police have questions, they can call an answering service and be put in touch with a prosecutor. ${ }^{91}$ The prosecutors take turns being on call for one week at a time. ${ }^{92}$ Calls are rare, however, and typically happen only in "high profile or unusual cases." ${ }^{93}$ In Prince George's County, Maryland, prosecutors are available by phone at all hours, but they do not give final direction about whether police should charge, and in fact, calls are "pretty rare and only in a high-profile or unusual case." ${ }^{44}$ Similarly, in Baltimore County, Maryland, calls are not mandatory and officers must page a prosecutor on duty to ask question. ${ }^{95}$

Lee County, Florida (home to Fort Myers) also has a phone number for police to ask questions about probable cause, but the prosecutors "will not tell an officer to arrest a person." ${ }^{96}$ Calls are "pretty rare" and are typically for "unusual" and "high-profile" cases, usually involving murders. ${ }^{97}$ Indeed, in cases in Lee County, the prosecutor does not become involved in the case until arraignment and typically reviews the file for the first time " 10 to 15 days after arrest." $"$ "In Portsmouth County, a medium-sized county in Virginia, a prosecutor is on call twenty-four hours a day to answer questions from police, but phone calls are "fairly rare" and typically happen only in unusual cases. ${ }^{99}$ In the ordinary case, prosecutors do not become involved until after arraignment. ${ }^{100}$

Finally, in Hennepin County (Minneapolis), Minnesota, the prosecutor's office does not have a hotline but has prosecutors available twenty-four hours a day to answer questions from police. ${ }^{101}$ Yet calls from law enforcement are "rare and likely [only happen] in serious or high profile crimes." 102 Indeed, the office experimented with "having a prosecutor stay [in the office] until 7:00 p.m. to answer any questions the police might wish to ask." ${ }^{103}$ A prosecutor who participated in the pilot program noted, "I almost never got a call and we terminated

90. See, e.g., E-mail from Mike Frawley, Ventura Cty. Dist. Attorney's Office, to Elizabeth Lester (June 14,2017 ) (on file with author).

91. See id.

92. See id.

93. Id.

94. See E-mail from Leslie W. Graves, Prince George's Cty. Dist. Attorney's Office, to Elizabeth Lester (June 19, 2017) (on file with author).

95. See Interview with Officer Patrick Helphensteine, Balt. Cty. Police Dep't (June 9, 2017) [hereinafter Helphensteine Interview].

96. E-mail from Kelly S. Worcester, Assistant Dist. Attorney, Lee Cty. Fla., to Elizabeth Lester (June 14, 2017) (on file with author).

97. $I d$.

98. Id.

99. E-mail from Stephanie Morales, Portsmouth Commonwealth's Attorney, to author (Aug. 17, 2017) (on file with author).

100. See id.

101. See E-mail from Alan Harris, Managing Assistant Hennepin Cty. Attorney, to author (June 7, 2017).

102. Id.

103. Id. 
the experiment." ${ }^{104}$ Accordingly, in Hennepin County, prosecutors ordinarily do not see cases until thirty-six to sixty hours after arrest. ${ }^{105}$

The twelve counties described above have created a specific hotline or call procedure for police to seek advice from prosecutors about warrantless arrests. Yet all the counties indicated that calls are rare and typically only occur in highprofile, very serious, or very unusual cases.

\section{Counties with More Frequent Police-Prosecutor Interactions}

Some jurisdictions responded that their prosecutors have more frequent interactions with police about warrantless arrests. For instance, San Diego, California assigns one prosecutor to be on site at the police department and another to be on site at the sheriff's department. ${ }^{106}$ These prosecutors are available to answer questions from police, for instance in narcotics investigations. ${ }^{107} \mathrm{~A}$ thirtyyear veteran prosecutor in the San Diego office, however, explained that prosecutors "never tell anyone in law enforcement whether they should arrest someone [because] it's not our job." ${ }^{108}$ Rather, in the ordinary case, prosecutors first touch the case about forty-eight hours after arrest. ${ }^{109}$

Other jurisdictions use a more traditional hotline and report that calls from police happen with some frequency. For example, in San Bernardino County, California, prosecutors make themselves available to police by phone. ${ }^{110}$ While police are not obligated to speak with prosecutors prior to making warrantless arrests, officers do contact prosecutors in a variety of cases when there are legal or factual issues they need clarification on. ${ }^{111}$ Similarly, in Nassau County (Long Island), New York, prosecutors staff a hotline twenty-four hours a day, and police call "fairly frequently" to seek advice on warrantless arrests. ${ }^{12}$ In Nassau County, however, officers are not obligated to call the hotline and the prosecutors "do not dictate" when the police should arrest. ${ }^{113}$

Multiple offices in Massachusetts indicated that they answer questions from police twenty-four hours per day and that calls are not rare. ${ }^{114}$ In Worcester, Massachusetts, calls are not mandatory, but "communication is frequent," particularly in homicide and motor vehicle crash cases. ${ }^{115}$ Just a short drive down

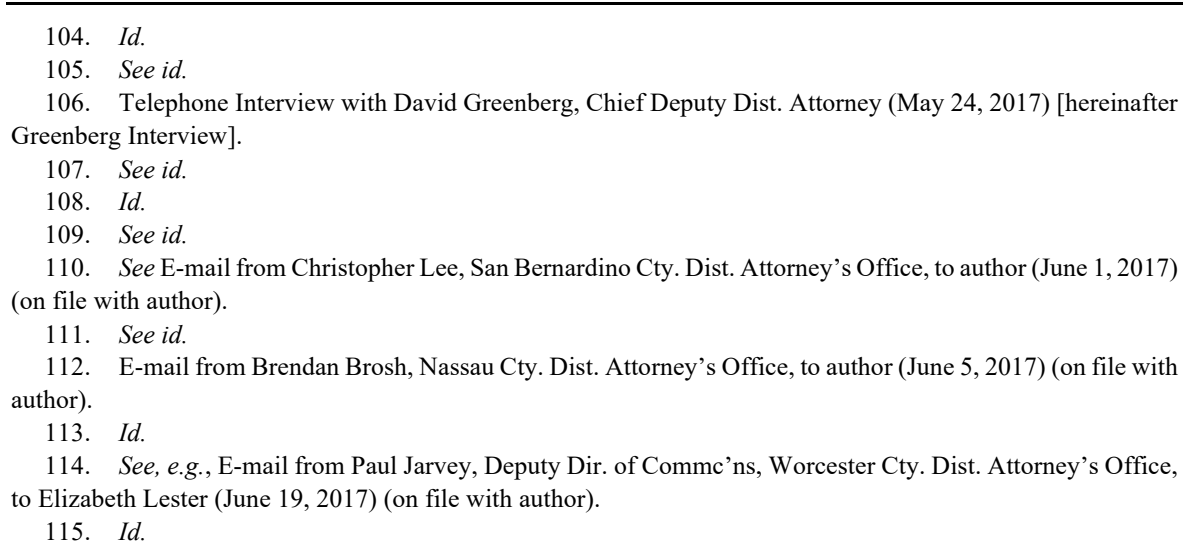


the road, in Norfolk, Massachusetts, prosecutors also have a twenty-four-hour hotline that is staffed by senior attorneys. ${ }^{116}$ Police are not obligated to seek input from prosecutors, but calls are "not at all rare," nor are they solely for high-profile cases. ${ }^{117}$ In Essex County, Massachusetts (home to Salem), prosecutors staff a phone line so police can consult on "many issues," including whether to make warrantless arrests. ${ }^{118}$ Nevertheless, even though there are a limited number of offenses in Massachusetts for which police can make warrantless arrests, officers are not obligated to call because "it would be impossible for police to call us in every case." 119

In Snohomish County, Washington, prosecutors rotate on a weekly basis to answer calls from police. ${ }^{120}$ The officers are not required to call prosecutors prior to arrest, but police typically call prosecutors for the most serious felonies, such as murder and rape, and they also call when there are unique circumstances. ${ }^{121}$ Similarly, in Jefferson County, Kentucky (home to Louisville), certain divisions (such as homicide, fraud, child abuse, and consumer protection) have a prosecutor liaison for police to consult with directly about cases. ${ }^{122}$ Police can call prosecutors at any time of day, though they are not required to do so. ${ }^{123} \mathrm{In}$ Will County, Illinois (home to Joliet), police are not obligated to call prior to warrantless arrests, but an experienced prosecutor wears a pager twenty-four hours a day to answer any questions police may have. ${ }^{124}$ According to a Will County prosecutor, police from larger precincts tend not to call very often, whereas officers from smaller precincts do tend to call, though primarily in felony cases. ${ }^{125} \mathrm{In}$ Gwinnett, Georgia, police are able to page a prosecutor's cell phone twenty-four hours a day. ${ }^{126}$ Calls are not mandatory, and according to a Gwinnett County prosecutor, police call prosecutors about three or four times a day. ${ }^{127}$

A few jurisdictions go further by not only maintaining a hotline for police to call but also mandating calls prior to certain types of warrantless arrests. In Shelby County, Tennessee (home to Memphis), police officers are required to contact the prosecutor's office prior to making a warrantless arrest for homicide,

\footnotetext{
116. See E-mail from David Traub, Norfolk Cty. Dist. Attorney's Office, to Elizabeth Lester (June 28, 2017) (on file with author).

117. Id.

118. See E-mail from Carrie Kimball-Monahan, Dir. of Commc'ns, Essex Cty. Dist. Attorney's Office, to Elizabeth Lester (June 14, 2017) (on file with author).

119. Id.

120. See Telephone Interview with Bob Lenz, Chief of Operations, Snohomish Cty. Dist. Attorney's Office (June 14, 2017) [hereinafter Lenz Interview].

121. See id.

122. See E-mail from Jeffrey Cooke, Jefferson Cty. Dist. Attorney's Office, to Elizabeth Lester (June 16, 2017) (on file with author).

123. See id.

124. See Interview with Kathy Patton, Assistant State's Attorney, Will Cty. Dist. Attorney's Office, in Joliet, Ill. (June 22, 2017) [hereinafter Patton Interview].

125. See id.

126. See Interview with Ron Blackburn (June 26, 2017) [hereinafter Blackburn Interview].

127. See id.
} 
armed robbery, and some other violent crimes. ${ }^{128}$ The reason is not only to help police select the correct charges but also to ensure that all possible evidence is collected. ${ }^{129}$ In Essex County, New Jersey (home to Newark), prosecutors are "involved in the charging decisions in virtually all the [homicide] cases prior to arrest" but do not advise the police on lower-level street arrests. ${ }^{130}$ In Lake County, Illinois, prosecutors screen all felony and domestic violence cases prior to arrests. ${ }^{131}$ This amounts to roughly forty calls per day from police to prosecutors. ${ }^{132}$

Finally, some prosecutors' offices counseled that even though hotline calls are rare, it is possible that police are calling individual prosecutors who they have strong working relationships with. For instance, in Las Vegas, Nevada, the Clark County District Attorney's Office does not have a hotline for police to call with questions about warrantless arrests, but it does have a phone number for police to call for help with search warrants. ${ }^{133}$ A Clark County prosecutor explained that for every roughly sixty calls to the search warrant number, about four calls are from police asking for advice about warrantless arrests. ${ }^{134}$ The prosecutor also explained that some police likely call prosecutors who they work closely with. ${ }^{135}$

In sum, a number of counties reported that their prosecutors had some interaction with police at the moment of warrantless arrests. In a few of these jurisdictions calls were mandatory for certain particularly serious offenses. In most, however, the police still had discretion whether to consult with prosecutors or not.

In total, after gathering information from forty large and medium-sized prosecutors' offices, I found very limited prosecutorial prescreening of warrantless arrests. ${ }^{136}$ Some offices acknowledged doing virtually no prescreening. ${ }^{137}$ Many offices staff prosecutors to answer calls from the police, but noted that calls were infrequent. ${ }^{138} \mathrm{~A}$ few prosecutors' offices reported that calls happen regularly but noted that those calls are typically only in the most serious felony cases. ${ }^{139}$ Other offices cautioned that it is impossible to determine the amount of

128. E-mail from Vince Higgins, Office of Shelby Cty. Dist. Attorney's Office, to author (May 23, 2017, 2:43 PM) (on file with author).

129. See, e.g., Lenz interview, supra note 120.

130. E-mail from Katherine Carter, Pub. Info. Officer, Essex Cty. Prosecutor's Office, to author (May 30, 2017).

131. See E-mail from Cynthia Vargas, Commc'ns Manager, Lake Cty. State's Attorney's Office, to Elizabeth Lester (June 12, 2017).

132. See id.

133. See Interview with Nelle Christianson, Assistant Dist. Attorney (June 19, 2017) [hereinafter Christianson Interview].

134. See id

135. See id.

136. My study sets aside highly unusual cases, in which prosecutorial involvement prior to arrest is quite different. See Kate Levine, How We Prosecute the Police, 104 GEO. L.J. 745, 762-64 (2016) (describing considerable pre-arrest vetting by prosecutors when police officers are the suspects).

137. See, e.g., E-mail from Brian Feinberg, supra note 50.

138. See id.

139. See, e.g., E-mail from Cameron L. Kline, supra note 54. 
advice being given to police because some police officers check with individual prosecutors with whom they have close working relationships. ${ }^{140}$ Finally, a small number of jurisdictions mandate that police clear serious felony arrests with prosecutors in advance. With the exception of one office that required prescreening of domestic violence cases, however, none of the offices discussed above required any prosecutorial involvement in warrantless misdemeanor arrests. ${ }^{141}$

A few jurisdictions reported that prosecutors review warrantless arrests within twelve hours. ${ }^{142}$ More commonly, prosecutors stated that they see cases for the first time about thirty-six to forty-eight hours after arrest. ${ }^{143}$ One county noted that its prosecutors typically do not see cases until two weeks after arrest, while another jurisdiction acknowledged not appearing at the probable cause hearing and thus not reviewing warrantless arrests until weeks or months later. ${ }^{144}$

\section{The Reasons for Limited Prosecutorial Involvement Prior to Arrest}

As detailed above, most jurisdictions have limited involvement in advising police prior to warrantless arrests. Prosecutors' offices offered two main reasons why their attorneys do not take a more hands-on role in screening cases at the moment of arrest: (1) screening warrantless arrests would be labor-intensive and thus prohibitively expensive; and (2) prosecutorial involvement in screening warrantless arrests would risk the loss of absolute immunity that courts typically afford to prosecutors. ${ }^{145}$

A few prosecutors' offices noted the considerable cost and logistical challenge of having prosecutors involved in warrantless arrests. ${ }^{146}$ For instance, the Essex County, New Jersey office explained that "[w]ith approximately 250 arrests a week in Newark - the largest city in our jurisdiction-consulting a prosecutor prior to each arrest would be a tremendous undertaking." 147 Similarly, a Los Angeles prosecutor stressed the logistical challenge of having prosecutors deal with more than 100 law enforcement agencies in a county with a population of 10 million people. ${ }^{148}$

In addition to logistics and cost, some prosecutors' offices expressed concerns about exposing their offices and staff to civil liability. ${ }^{149}$ Prosecutors have absolute immunity for actions taken in their prosecutorial capacity. ${ }^{150}$ When prosecutors act in an investigative capacity, however, they are only entitled to

\footnotetext{
140. See E-mail from Carrie Kimball-Monahan, supra note 118.

141. See, e.g., E-mail from Jeffrey Cooke, supra note 122.

142. See, e.g., E-mail from Cameron L. Kline, supra note 54.

143. See, e.g., E-mail from Steve E. Wright, supra note 45.

144. See supra notes 89,98 , and accompanying text.

145. See supra note 71 and accompanying text; infra note 152 and accompanying text.

146. See E-mail from Katherine Carter, supra note 130; E-mail from Devallis Rutledge, supra note 43.

147. See E-mail from Katherine Carter, supra note 130.

148. See E-mail from Devallis Rutledge, supra note 43.

149. See id.; E-mail from Steve E. Wright, supra note 45.

150. See Imbler v. Pachtman, 424 U.S. 409, 427 (1976); Margaret Z. Johns, Reconsidering Absolute Prosecutorial Immunity, 2005 BYU L. REV. 53, 80-89 (discussing Imbler and other cases).
} 
qualified immunity. ${ }^{151}$ Prosecutors in Clark County (Las Vegas); Suffolk, New York; Contra Costa, California; Fresno, California; and Los Angeles, California all expressed concern that too great of involvement in advising police could result in the prospect of civil liability. ${ }^{152}$ Moreover, one New York prosecutor explained that the legislature had taken steps to authorize indemnification of police - but not prosecutors-for civil judgments. ${ }^{153}$

The cost, logistics, and liability concerns voiced by multiple prosecutors' offices are surely sincere. As explained below, however, limited involvement by prosecutors at the moment of warrantless arrest likely results in a large number of weak cases being put into the criminal justice system. ${ }^{154}$ This has ramifications for jailers, defendants, clerks, judges, public defenders, and the prosecutors themselves.

\section{Problems with Limited Prosecutorial Oversight of Police Decisions to Make Warrantless Arrests}

As Section II.B demonstrates, in the vast majority of cases, police make warrantless arrests without first consulting a prosecutor. In many counties, however, there is no prosecutorial review of warrantless arrests for thirty-six to fortyeight hours, until the judge conducts a probable cause hearing. ${ }^{155}$ And at that hearing, prosecutors may not examine the case thoroughly. ${ }^{156}$ In two jurisdictions I spoke with, prosecutors do not even appear at the probable cause hearing and do not become involved in the case until weeks or months later. ${ }^{157}$ Late and limited prosecutorial review creates a number of problems for not just the arrestees but also for prosecutors and other actors in the criminal justice system.

\section{Evidence Collection and Trial Problems for Prosecutors Down the Road}

If prosecutors are not consulted about warrantless arrests, they are not able to communicate to police the need to seize and log certain evidence. Police are trained investigators, but they typically have very little legal training and may not be well positioned to understand all of the evidence the prosecution may need to prove each element of a case. ${ }^{158}$

For example, in a domestic assault case, a patrol officer might not recognize the importance of taking pictures of all of the victim's injuries at the scene. If the complainant tells the officer she plans to press charges, the officer may take the suspect into custody and assume the victim will cooperate with prosecutors down

151. See Buckley v. Fitzsimmons, 509 U.S. 259, 273 (1993).

152. See Christianson Interview, supra note 133; E-mail from Devallis Rutledge, supra note 43, E-mail from Steve E. Wright, supra note 45.

153. See Miller Interview, supra note 56.

154. See infra notes $244-46$ and accompanying text.

155. See, e.g., E-mail from Steve E. Wright, supra note 45.

156. See Harmon, supra note 18 , at 341 .

157. See E-mail from Jamie Beck, supra note 88; E-mail from Kelly S. Worcester, supra note 96.

158. See Wayne A. Logan, Police Mistakes of Law, 61 EMORY L.J. 69, 103-09 (2011) (describing limited substantive criminal law training provided to police). 
the road to demonstrate her injuries. Unfortunately, many domestic violence victims later recant their complaints and refuse to cooperate with the prosecution. ${ }^{159}$ Weeks later, the victim's injuries will no longer be visible and without photographs the prosecutor will have to dismiss the case. ${ }^{160}$

Police might also fail to appreciate the importance of forensic testing. Police might not insist a nurse conduct a forensic examination of a sexual assault victim, thus losing valuable evidence. ${ }^{161}$ Or police might erroneously assume that because forensic testing is unlikely to turn up fingerprints or DNA that it is not worth doing. Yet, as prosecutors know, not testing evidence (even if it is unlikely to turn up anything incriminating) can be devastating in the eyes of a jury. For instance, if police do not test a gun or a bag for fingerprints or DNA, the defense attorney can turn to the jury and say: "The police did not even test for possible evidence!" Because police do not have experience trying cases, they do not have the same perspective as prosecutors who know the importance of checking all of the boxes in the eyes of the jury. ${ }^{162}$

159. See Jim Leckrone \& Mary Wisniewski, Study Shows Why Domestic Violence Victims Drop Charges, REUTERS (Aug. 19, 2011, 4:21 PM), http://www.reuters.com/article/us-domestic-violence-study-idUSTRE77I 6FE20110819.

160. See Interview with Ed McClees, former Harris Cty. prosecutor (June 6, 2017) [hereinafter McClees Interview].

161. See id.

162. See id. 


\section{Harm to Arrestees Caused by Lack of Prosecutorial Involvement}

a. Unnecessary Arrests: Police File Charges That Prosecutors Would Not Have Brought

Police arrest suspects in some-perhaps many-cases that prosecutors never would have arrested in. ${ }^{163}$ At a broad level, we know this because prosecutors dismiss an enormous percentage of cases after police have filed charges. ${ }^{164}$ On average, prosecutors dismiss $25 \% 165$ of felony charges, and in some jurisdictions that number can be as high as $40 \%$ or $50 \% .{ }^{166}$ In her recent study of New York City, Professor Issa Kohler-Hausmann found that prosecutors declined to prosecute between 17,000 and 30,500 misdemeanor arrests each year. ${ }^{167}$ There are at least two big-picture types of cases prosecutors dismiss outright without a plea bargain: (1) cases in which prosecutors recognize they could never prove the necessary elements of the crime charged; and (2) cases in which the prosecutor could prove all of the elements but determines, in the interest of justice, that some or all of the charges should be dismissed.

Let's start with the cases that prosecutors cannot prove. Imagine that a police officer sees someone driving erratically and the officer turns on his siren and lights to pull over the car. Imagine also that the driver, while not speeding, does not immediately pull over his vehicle. The officer arrests the driver not for the original traffic offense, but for evading arrest because of the delay in pulling over. It is not uncommon for police to claim a suspect was evading arrest. ${ }^{168}$ Prosecutors know, however, that to prove evasion they must show that the driver intentionally fled from a person he knew was a law enforcement officer. ${ }^{169}$ But the driver might not have initially seen the police car in his rear-view mirror. Or the driver might not have pulled over immediately because he was nervous and did not see a place to safely pull off the road. Or, even if those stories are not true, the prosecutor knows that a defense attorney could very easily convince a jury that reasonable doubt exists. ${ }^{170}$ So, while police are keen to arrest for evading arrest, prosecutors are not. ${ }^{171}$

Consider the related crime of resisting arrest. Imagine that a police officer is making a valid arrest for driving while intoxicated. The officer pulls the

\footnotetext{
163. See Anna Roberts, Dismissals as Justice, 69 ALA. L. REV. 327, 342 (2017).

164. See REAVES, supra note 4 , at 24 tbl.21.

165. See id. Although it has largely escaped attention, judges in a minority of states also have the power to dismiss cases. See Roberts, supra note 163, at 330 (exploring judicial power in nineteen states).

166. See REAVES, supra note 4, at 22. Of course, many of these dismissals happen down the road when a witness recants, or other factual information becomes clearer. But in a sizable number, prosecutors likely would know at the very outset that the case would be dismissed.

167. See Kohler-Hausmann, supra note 31, at 645.

168. Interview with Laura Killinger, former Harris Cty. prosecutor (June 3, 2017) [hereinafter Killinger Interview].

169. See, e.g., TeX. Penal Code AnN. § 38.04 (West 2019).

170. See Jonathan Abel, Cops and Pleas: Police Officers' Influence on Plea Bargaining, 126 YALE L.J. 1730, 1747 (2017) ("Police think in terms of 'probable cause' (the standard for arrest), while prosecutors think in terms of 'reasonable doubt' (the standard for conviction).").

171. See Killinger Interview, supra note 168.
} 
driver's hands behind his back to handcuff them. The driver-perhaps because he is drunk and not in firm control of his bodily movements, or perhaps because having his hands pulled by the officer is painful-recoils and pulls his hands away from the officer. In this common scenario, police sometimes seek charges for resisting arrest. Prosecutors, on the other hand, are more skeptical and ultimately dismiss some of the resisting cases. ${ }^{172}$

Similarly, when a suspect or his family or friends are verbally abusive during an arrest, police often want to file additional charges for making a terroristic threat because the suspect has threatened imminent violence. ${ }^{173}$ These charges can be legitimate if the suspect makes a realistic and imminent threat, but often suspects are simply mouthing off and engaged in tough talk. Prosecutors often dismiss these charges. ${ }^{174}$

Examples are not limited to the "contempt of cop" situations outlined above. Police and prosecutors see many cases differently, with police often focused on the moment of arrest, while prosecutors think about whether a conviction is likely. ${ }^{175}$ For example, as Professor Alexandra Natapoff has observed, police sometimes arrest "to clear a street corner, to manifest a police presence in a high-crime neighborhood, [or] to induce cooperation from potential witnesses." ${ }^{176}$ Similarly, according to sociologist and former police officer Peter Moskos, police in Baltimore regularly order people to "move on" and arrest them if they do not comply. ${ }^{177}$ In New York, between 1992 and 2004, police continued to make thousands of loitering arrests even after the Second Circuit had struck down the loitering statute and enjoined the City from filing charges under it. ${ }^{178}$ Police may think that arresting in these types of cases is the appropriate course of action for "maintaining order," 179 but prosecutors will often dismiss these cases because they are impossible to prove. ${ }^{180}$

Or imagine that an individual brings a gun through airport security-a problem that happens more than 3,000 times per year in the United States. ${ }^{181}$

\footnotetext{
172. See id.

173. See, e.g., TeX. Penal Code AnN. § 22.07 (West 2019).

174. See Interview with Danny Lacayo, former Harris Cty. prosecutor (June 7, 2017) [hereinafter Lacayo Interview].

175. See Abel, supra note 170.

176. Alexandra Natapoff, Misdemeanors, 85 S. CAL. L. REv. 1313, 1332 (2012). Police also may arrest for other "order maintenance" reasons such as a desire to conduct a search or interrogation, or to procure DNA evidence or mug shots. See Josh Bowers, Legal Guilt, Normative Innocence, and the Equitable Decision Not to Prosecute, 110 Colum. L. REV. 1655, 1695 (2010); Harmon, supra note 18, at 356-57.

177. See Peter Moskos, Cop in the Hood: My Year Policing Baltimore's Eastern District 114-17

178. See Charlie Gerstein \& J.J. Prescott, Process Costs and Police Discretion, 128 HARV. L. ReV. F. 268, 275 (2015).

179. See id. at 271.

180. See Natapoff, supra note 176, at 1336 (noting that prosecutors dismiss one-third of Baltimore loitering

181. See Fredrick Kunkle, Trump Aide Was Among Record Numbers Taking a Gun Through TSA Checkpoint Last Year; Police Say, WASH. POST (Jan. 27, 2017), https:/www.washingtonpost.com/news/tripping/wp/
} (2008). arrests). 
Many law enforcement officers want to file charges for bringing a weapon into a prohibited area, surely because they think charges are truly merited. ${ }^{182}$ Yet prosecutors know that those cases are very difficult to prove. ${ }^{183}$ Defendants can make a plausible (and often true) claim that they simply forgot the weapon was in the bag. ${ }^{184}$ Because some state statutes require the defendant to have intentionally brought the weapon into an airport, ${ }^{185}$ many prosecutors will dismiss those charges. ${ }^{186}$

In addition to cases that are difficult to prove, prosecutors sometimes dismiss cases as a matter of justice, even though police would have followed through on charges. ${ }^{187}$ For example, one former prosecutor relayed a story of police seeking to arrest a suspect for siphoning $\$ 40$ worth of gas out of an automobile. ${ }^{188}$ Police sought to charge the suspect with burglary of a motor vehiclea felony - because theft of $\$ 40$ was a low-level offense that carried no jail time. ${ }^{189}$ Although the prosecutor recognized that it might be theoretically possible to meet the elements of the burglary statute by siphoning gas, she believed in the interests of justice that the case did not merit felony charges. ${ }^{190}$

Or imagine that police catch a suspect with half-a-dozen different types of drugs and arrest him for intent to distribute. Each different type of drug is a different offense, and the police officer may want to charge six offenses. The prosecutor, however, may not see the point in filing six separate charges and will instead drop most of the charges for the less serious drugs. ${ }^{191}$

Finally, while most police are honorable and hardworking, some departments pressure officers to numerically justify what they have done on their shifts. ${ }^{192}$ An officer with few or no arrests might have worked hard and effectively for the community but have no way to show it to superior officers. In a world where CompStat is prevalent and officers in some departments are pressured to bring in good statistics, ${ }^{193}$ it should not be surprising that police might

\footnotetext{
2017/01/27/trump-aide-was-among-record-numbers-taking-a-gun-through-tsa-checkpoint-last-year/?noredirect $=$ on\&utm_term $=.6 \mathrm{fd} 4 \mathrm{~d} 8 \mathrm{f} 4450$ a (noting that the TSA found more than 3,300 firearms in carryon bags in 2016).

182. Id

183. Id.

184. Id

185. See, e.g., TeX. Penal Code AnN. § 46.03(a)(5) (West 2019).

186. I am grateful to former Harris County prosecutor Ed McClees for this example.

187. Police may become upset by prosecutors' "nullification" of charges and try to exert pressure on prosecutors to proceed. See Bowers, supra note 176, at 1700-01; Roger A. Fairfax, Jr., Prosecutorial Nullification, 52 B.C. L. REV. 1243, 1271 (2011). Moreover, as Professor Rachel Harmon has argued, there are many instances in which police could resolve situations with citations rather than by making an arrest. See Harmon, supra note 18 , at $332-43$.

188. See Killinger Interview, supra note 168

189. Id.

190. Id.

191. I observed prosecutors repeatedly do this during an intake shift at the Harris County District Attorney's Office. See infra note 252.

192. See John A. Eterno \& Eli B. Silverman, The Crime numbers Game: Management by MANIPULATION 24-26 (2012).

193. See id.
} 
(either purposefully or subconsciously) make more arrests than prosecutors would make.

In short, there is good reason to believe that there would be considerably fewer arrests if police consulted with prosecutors at the moment of a warrantless arrest. These "unnecessary arrests" are not simply erased when prosecutors later drop the charges. To the contrary, as explained below, arrestees suffer considerable harm up to and after the charges are dismissed.

\section{b. Arrest Reports and Mug Shots: The Internet Remembers}

For defendants, an unnecessary arrest is not just about spending a night (or many nights) in jail. Unnecessary arrests also create unwanted publicity and a permanent internet record that can hinder the arrestee for years to come. ${ }^{194}$

First, many newspapers publish a police blotter that lists all arrests made by the police. ${ }^{195}$ Once printed, the arrest record exists on the Internet forever and can negatively impact a suspect when applying for a job.

Additionally, arrestees are photographed, and increasingly their mug shots are placed into the public domain. ${ }^{196}$ Local newspapers and media outlets publish some mug shots, with prostitution cases being a common example. ${ }^{197}$ Worse yet, dozens of enterprising (and unseemly) companies publish mug shots on their websites in an effort to extort money. ${ }^{198}$ Some of these websites invite individuals to pay anywhere from $\$ 30$ to $\$ 400$ to remove their mug shots. ${ }^{199}$ But, of course, even if the individual pays, the mug shot may simply turn up on another site, ${ }^{200}$ and the individual will have to turn to expensive removal services to clean up their internet profile. ${ }^{201}$

If an arrestee's mug shot remains on the internet - as many of them do-it will be easily discoverable by potential employers. In some instances, this may be a good thing: society does not want dangerous people being hired to work with children and other vulnerable populations. For many individuals, however, a prior arrest - perhaps from when they were in college - is no longer relevant. It is particularly irrelevant if the charges were dropped and the person was never

194. See infra notes 195, 197, 199.

195. See James B. Jacobs, Mass Incarceration and the Proliferation of Criminal Records, 3 U. ST. THOMAS L.J. 387, 406 (2006).

196. See infra notes $197,199$.

197. See Art Hubacher, Comment, Every Picture Tells a Story: Is Kansas City's “John TV” Constitutional?, 46 KAN. L. REV 551, 558-59 (1998).

198. See infra note 199.

199. See Euemi K. Lee, Monetizing Shame: Mugshots, Privacy, and the Right to Access, 70 RUTGERS U. L. REV. 557, 559 (2018); Allen Rostron, The Mug Shot Industry: Freedom of Speech, Rights of Publicity, and the Controversy Sparked by an Unusual New Type of Business, 90 WASH. U. L. REV. 1321, 1322-24 (2013); David Segal, Mugged by a Mug Shot Online, N.Y. TIMES (Oct. 5, 2013), https://www.nytimes.com/2013/10/06/business/mugged-by-a-mug-shot-online.html.

200. See Segal, supra note 199.

201. Observers have called this the "Mugshot Racket." See Michael Polatsek, Note, Extortion Through the Public Record: Has the Internet Made Florida's Sunshine Law Too Bright?, 66 FLA. L. REV. 913, 918 (2014). 
convicted of a crime. ${ }^{202}$ Yet if the mug shot is the first thing that shows up in an internet search, it will surely have a deleterious effect when the person applies for work. ${ }^{203}$ For instance, in one high-profile case, a domestic violence victim who was wrongfully arrested by the police had to contend with her mug shot being all over the internet as she finished medical school and sought employment. $^{204}$

Put simply, when police decide to make a warrantless arrest, the consequences may last forever, even if the criminal case is ultimately dismissed.

\section{c. Bail Costs Money, and Inability to Post Bail Leads to Job Loss}

The next obvious problem with unnecessary arrests is the cost of bail. In the not-so-distant past, arrestees were commonly released on their own recognizance. ${ }^{205}$ Not so any longer. ${ }^{206}$ Now a majority of felony defendants in large counties have to come up with cash to get out of jail. ${ }^{207}$ Recognizance bonds in misdemeanor cases are still common, but in many places they are far less common than in the past. ${ }^{208}$ For suspects who are middle-class or wealthy, this is obviously not much of a problem. They post a cash bond and, if they comply with the conditions of their release, they receive the cash back when their case is dismissed. $^{209}$

Most suspects are not wealthy or even middle-class, however. ${ }^{210}$ Most arrestees are poor and do not have thousands of dollars, or even hundreds of dollars, available to use for bail. ${ }^{211}$ Some poor suspects therefore turn to family to scrape together bail money. Families then undergo hardship by selling their possessions or foregoing basic life necessities to come up with bail money. ${ }^{212}$

More commonly, bail amounts are simply too high for the suspect and his family to meet. Arrestees therefore turn to bail bondsman who will post the entire

\footnotetext{
202. See Segal, supra note 199 .

203. Id.

204. See id. Additionally, the mug shot may cause trouble for individuals as they try to form romantic and other personal relationships.

205. See REAVES, supra note 4, at 20 (showing that in 1990, large counties required money bonds in less than $40 \%$ of cases and that by 2009 , the percentage had risen to $60 \%$ ).

206. Id.

207. See id.

208. See Paul Heaton et al., The Downstream Consequences of Misdemeanor Pretrial Detention, 69 STAN. L. REV. 711, 716 (2017) (explaining that half of misdemeanor defendants in Harris County are detained pretrial and that "[o]ther jurisdictions also detain people accused of misdemeanors at surprising rates."). Recent litigation in Houston has focused on cash bail requirements and pretrial detention of indigent low-level misdemeanor defendants. See Eli Rosenberg, Judge in Houston Strikes Down Harris County's Bail System, N.Y. Times (Apr. 29, 2017), https://www.nytimes.com/2017/04/29/us/judge-strikes-down-harris-county-bail-system.html.

209. See Heaton et al., supra note 208, at 721 .

210. Id. at 737 .

211. See Cherise F. Burdeen, The Dangerous Domino Effect of Not Making Bail, AtLAnTIC (Apr. 12, 2016), https://www.theatlantic.com/politics/archive/2016/04/the-dangerous-domino-effect-of-not-making-bail/477

212. See Samuel R. Wiseman, Pretrial Detention and the Right to Be Monitored, 123 YALE L.J. 1344, 136061 (2014).
} $906 /$. 
bond if the suspect pays $10 \%$ up front. ${ }^{213}$ The rub, however, is that even if all goes well and the case is dismissed, the bondsman keeps the $10 \% .{ }^{214}$ And $10 \%$ can be a lot of money for poorer members of society. For example, the bail schedule in Los Angeles, California sets bail at $\$ 5,000$ for loitering on private property, $\$ 20,000$ for battery of a police officer, and $\$ 25,000$ for making criminal threats. ${ }^{215}$ If the suspect is fortunate enough to come up with $10 \%$ to pay the bail bondsman, he will have spent hundreds or even thousands of dollars, which may be the difference between paying next month's rent and being out on the street.

Matters will be far worse though for the arrestees who cannot afford the $10 \%$ to pay a bail bondsman and who must remain in jail. ${ }^{216}$ These arrestees will remain incarcerated for weeks or months. Unable to make it to work, many will lose their jobs, which in turn will cause a cascade of other financial and basic life problems. Some vulnerable populations - those in drug treatment or homeless shelters - may lose their beds in the facilities. ${ }^{217}$ They might even suffer violence while incarcerated. For example, in 2014, Tyrone Tomlin was arrested for possession of drug paraphernalia because a police officer incorrectly believed his soda straw was paraphernalia for snorting cocaine. ${ }^{218}$ The judge set bail at $\$ 1,500$, but Tomlin was living paycheck to paycheck and had no money to spare. ${ }^{219} \mathrm{He}$ was sent to Riker's Island for three weeks, where he was brutally assaulted by other inmates. ${ }^{220}$ Only weeks later did prosecutors look carefully at his case and dismiss the charge. ${ }^{221}$

d. Wrongful Guilty Pleas, Lost Wages, Anxiety, and Collateral Costs of Unnecessary Arrests

Mug shots and bail are two obvious consequences of being arrested, but the pain of the criminal justice process does not end there.

For some misdemeanor arrestees, an unnecessary arrest leads to a wrongful conviction. If a suspect cannot make bail, he will be incarcerated while he waits for a prosecutor to review his case. ${ }^{222}$ And in some jurisdictions, prosecutors do not appear at the probable cause hearing. ${ }^{223}$ Indeed, in some offices, prosecutors

\footnotetext{
213. See Heaton et al., supra note 208, at 721.

214. See 4 Wayne R. LaFaVe et al., Criminal Procedure § 12.1(b) (4th ed. 2015).

215. See SUPERIOR COURT OF L.A. CTY., 2018 BAIL SCHEDULE FOR INFRACTIONS AND MisDEMEANORS 12, 15, 20 (2018), https://www.lacourt.org/division/criminal/pdf/misd.pdf.

216. See Sabri Ben-Achour, When You Can't Make Bail, MARKETPLACE (July 27, 2016, 4:58 PM), https:// www.marketplace.org/2016/07/25/world/when-you-cant-make-bail.

217. See Allard K. Lowenstein, Int'L Human Rights Clinic, “ForCed into BREaking THE LaW”: The CRIMINALIZATION OF HOMELESSNESS IN CONNECTICUT 18 (2016), https:/law.yale.edu/system/files/documents/ $\mathrm{pdf} /$ news/criminalization_of_homelessness_report_for_web_full_report.pdf.

218. See Nick Pinto, The Bail Trap, N.Y. TIMES MAG. (Aug. 13, 2015), https://www.nytimes.com/ 2015/08/16/magazine/the-bail-trap.html.

219. Id.

220. Id.

221. Id.

222. Id.

223. See supra note 89 and accompanying text.
} 
do not look at warrantless arrest cases until days or weeks later. ${ }^{224}$ In those instances, the arrestee may simply plead guilty to get out of jail and get back to his family and his job. ${ }^{225}$ This pressure causes innocent individuals to plead guilty. ${ }^{226}$

For those who make bail, there will be future court appearances. This means taking time off from work and suffering anxiety and uncertainty. ${ }^{227}$ Prosecutors are extremely busy and may not focus enough attention on a case to dismiss it at the first court appearance. ${ }^{228}$ A prosecutor's later dismissal of a case does not restore the lost wages or undo emotional turmoil that accompanies the court appearances.

And then there are the collateral consequences outside the criminal justice system. For example, although the arresting officer may not know it, arrest records are used to make immigration removal decisions. ${ }^{229}$ Public housing authorities use arrest records to initiate eviction proceedings for failure to comply with leasing provisions about engaging in criminal activity. ${ }^{230}$ Employers and licensing entities use arrest information to monitor the off-duty activities of their workers. ${ }^{231}$ As Professor Eisha Jain explains, a "significant number of employers now also receive notifications whenever an employee is arrested and fingerprinted" and "[s]ome employers suspend or terminate at-will employees based on the arrest." 232 Some police departments also notify social services after a custodial parent has been arrested. ${ }^{233}$

In sum, even if a prosecutor dismisses a case shortly after arrest, much damage will already have been done. The individual will have suffered lost wages, anxiety, and a host of noncriminal collateral consequences. Not surprisingly, poor and minority individuals are more likely to suffer these consequences. ${ }^{234}$

\section{Burdening Other Criminal Justice Actors}

Unnecessary arrests also impose a burden on other actors working in the criminal justice system. First, and most obviously, the police themselves are burdened by unnecessary arrests. An average arrest takes several hours of officer

224. See id.

225. See Bowers, supra note 176, at 1708-10; Harmon, supra note 18, at 313; Jocelyn Simonson, Bail Nullification, 115 Mich. L. REV. 585, 589 (2017).

226. See Natapoff, supra note 176, at 1332; Wiseman, supra note 212, at 1355-56.

227. See Eisha Jain, Capitalizing on Criminal Justice, 67 DUKE L.J. 1381, 1395 (2018); Harmon, supra note 18 , at 313 .

228. See Adam M. Gershowitz \& Laura R. Killinger, The State (Never) Rests: How Excessive Prosecutorial Caseloads Harm Criminal Defendants, 105 Nw. U. L. REV. 261, 285-86 (2011).

229. See Eisha Jain, Arrests as Regulation, 67 StAn. L. REV. 809, 827-33 (2015).

230. See id. at 833-36.

231. Id. at 839-41.

232. Id. at $839-40$.

233. Id. at 841 .

234. See Paul D. Butler, Poor People Lose: Gideon and the Critique of Rights, 122 YALE L.J. 2176, 2183 (2013) ("The spaces that poor people, especially poor African Americans, live in receive more law enforcement in the form of police stops and arrests."); see also Jain, Arrests as Regulation, supra note 229, at 820 (discussing how public order policing strategies may disproportionately affect minority communities). 
time. ${ }^{235}$ That paperwork — which most officers hate ${ }^{236}$ - takes them off the street and away from protecting the public.

Following arrest, suspects are jailed. Some suspects will quickly make bail and leave the jails. But those who cannot afford the bail amount will languish, possibly for days or weeks. Many jails are overcrowded, ${ }^{237}$ and each additional inmate makes the facility more dangerous not just for the inmates but the sheriff's deputies who must safeguard the inmates. ${ }^{238}$ And incarcerating inmates is expensive. The average jail detention costs hundreds of dollars per day. ${ }^{239} \mathrm{Un}$ necessary arrests thus make jails more crowded, more expensive, and less safe.

Then there are the courtroom employees. Clerks must process all the cases. Judges must hold probable cause hearings. In many jurisdictions, prosecutors also appear at the probable cause hearings and must spend time, however fleeting, on these unnecessary arrests. ${ }^{240}$

If the case survives the probable cause hearing - and almost everyone agrees that the probable cause stage is not a stringent review ${ }^{241}$ - then the case will fully enter the system. Because the overwhelming majority of criminal defendants are indigent, they will be assigned to a public defender or receive an appointed a lawyer. ${ }^{242}$ And, as almost everyone knows, indigent defense lawyers in many jurisdictions have enormous caseloads that prevent them from devoting sufficient attention to each client. ${ }^{243}$

Of course, we should not hesitate to ask police, jailers, clerks, judges, prosecutors, and defense attorneys to do their jobs. But when the system is overloaded, should they be spending time - collectively, enormous amounts of time - on cases that will be dismissed and could have been screened out of the system up front? The answer to that question should be "no," and Part III below describes a framework for prosecutorial screening of warrantless arrests.

235. See Harmon, supra note 18 , at 319.

236. See Christine Hauser, To the Police Dept. It's Desk Duty. To Some Officers, It's More Like a Cellblock, N.Y. TIMES (Nov. 29, 2008), https://www.nytimes.com/2008/11/30/nyregion/30deskduty.html.

237. See Adam M. Gershowitz, Consolidating Local Criminal Justice: Should the Prosecutors Control the Jails?, 51 WAKE FOREST L. REV. 677, 683-85 (2016).

238. See U.S. Government Accountability Office, GAO-12-743, Growing InMate Crowding Negatively AfFects INMATES, StAFF, AND INFRASTRUCTURE 64-83 (2012), http://www.gao.gov/assets/650/ 648123.pdf.

239. See Shane Bauer, Inside the Wild, Shadowy, and Highly Lucrative Bail Industry, MOTHER JONES (May 2014), http://www.motherjones.com/politics/2014/06/bail-bond-prison-industry/.

240. Beyond the probable cause hearing, prosecutors must spend additional time on cases when they are initially charged as felonies rather than misdemeanors. For an insightful explanation of why prosecutors sometimes prefer cases to be charged as misdemeanors rather than felonies, see Paul T. Crane, Charging on the Margin, 57 WM. \& MARY L. REV. 775, 795-810 (2016) (explaining how misdemeanors carry fewer procedural protections for defendants but many of the same punishments and collateral consequences).

241. See, e.g., Williams v. Ward, 845 F.2d 374, 388 (2d Cir. 1988) (describing the burden at a probable cause hearing as "rather easily met").

242. See John D. King, Lamentations, Celebrations, and Innovations: Gideon at 50, 70 WASH. \& LEE L. REV. 835, 836 (2013).

243. See Mary Sue Backus \& Paul Marcus, The Right to Counsel in Criminal Cases: A National Crisis, 57 HASTINGS L.J. 1031, 1053-54 (2005). 


\section{The Harris County APProach: Prosecutorial SCREening BEFore ALl WARRANTLESS ARRESTS}

Up until the early 1970s, police in Harris County, Texas (home to Houston) filed charges by bringing cases to a justice of the peace ${ }^{244}$ Although the justices of the peace were supposed to reject cases in which all elements of the crime could not be proven, in practice, the judges and their administrative clerks were not an effective screening mechanism. ${ }^{245}$ Prosecutors were frustrated because they were spending a considerable amount of time on weak cases they believed should not have been filed in the first place. ${ }^{246}$ In 1973, the elected district attorney wrestled initial control of the cases away from the justices of the peace and established an "intake" office in which prosecutors, rather than judges or administrative clerks, would vet the cases brought in by police. ${ }^{247}$ Over four decades later, Harris County continues to have an intricate system in place in which prosecutors screen all warrantless arrests before charges are filed and before suspects are taken to jail. ${ }^{248}$

\section{A. The Structure of the Harris County Intake Process}

In Harris County, police officers cannot make any warrantless arrest without first calling the "intake hotline" and receiving approval from a prosecutor. ${ }^{249}$ If a prosecutor approves charges, the police can process the arrest; if the prosecutor rejects the charges, the officer must release the suspect. ${ }^{250}$ In short, no suspect can be locked up in Harris County without the case first being approved by a prosecutor. The process is quite intricate and has multiple checkpoint stages at which a prosecutor can reject charges.

The Harris County process starts with the officer making a call to the intake hotline and explaining the situation on the street to one of the intake prosecutors. ${ }^{251}$ If the prosecutor believes charges would be improper, the officer does not make the arrest and instead releases the suspect. ${ }^{252}$ If the prosecutor believes charges are merited, the officer then types up the defendant's name, the charges, the names of any witnesses, a statement of probable cause for the arrest, and the

244. My description of the history and current structure of the Harris County system in Sections II.A and II.B is based primarily on an interview with Jim Leitner, Bureau Chief of the Grand Jury and Intake Division, which I conducted at the Harris County District Attorney's Office on June 5, 2017.

245. Leitner Interview, supra note 6.

246. Id.

247. Id.

248. Id.

249. Officers are not obligated to call the intake line before charging a Class C misdemeanor because Class C offenses do not carry the possibility of jail time. See TEX. PENAL CODE $\S 12.23$ (West 2019). Those charged with class $\mathrm{C}$ offenses are ticketed and released.

250. See supra text accompanying note 8 .

251. See supra text accompanying note 7.

252. On occasion, the officer will ask to speak to a supervising prosecutor in an effort to overrule the intake prosecutor. Less frequently, when a prosecutor rejects the charges, an officer will try to do an end-run around the rejection by calling back and trying to speak with a different prosecutor. But, as described below, because there are only a few intake prosecutors working each shift, this end-run effort is rare and unlikely to succeed. 
name of the intake prosecutor who approved the charges. ${ }^{253}$ The officer then inputs that information into a computer database. ${ }^{254}$ Thereafter, an administrative assistant in the District Attorney's Office prints the file ${ }^{255}$ so that an intake prosecutor-typically someone other than the prosecutor who answered the phone call - can review it when there is a lull in calls to the hotline. ${ }^{256}$ This prosecutorial review is effectively a second bite at the apple. If there was a miscommunication during the initial phone call or if the screening prosecutor has concerns about the arrest, the prosecutor still has the option to reject charges. ${ }^{257}$ The paper screening of the case typically occurs within two hours of arrest. ${ }^{258}$

After the initial phone call and the paper copy review, the case proceeds to a third review. ${ }^{259}$ A different felony prosecutor in charge of the probable cause docket reviews the case and brings it before the magistrate who is conducting the probable cause hearings. ${ }^{260}$ This prosecutor-usually the third prosecutor to look at the case - also has the authority to reject charges and order the suspect released. ${ }^{261}$ Because there are typically nine probable cause dockets per day, this third prosecutor usually screens each case within a few hours of the initial arrest. ${ }^{262}$

In sum, three different Harris County prosecutors typically review each warrantless arrest before the case ever gets to a magistrate. ${ }^{263}$ The first prosecutor is in a position to stop the arrest from happening in the first place. The next two prosecutors are in a position to dismiss the case shortly after arrest and have the suspect released.

Running such an elaborate intake system is a considerable staffing commitment. There are typically five prosecutors assigned to the intake office at any given time. ${ }^{264} \mathrm{~A}$ division chief, who is a high-ranking senior attorney, oversees the entire intake system. ${ }^{265}$ Two senior felony prosecutors-one who answers intake calls and does paper screening and the other who is in charge of the probable cause docket — work full-time in that department. ${ }^{266}$ Another two lawyers who are more junior felony or misdemeanor prosecutors also answer calls to the

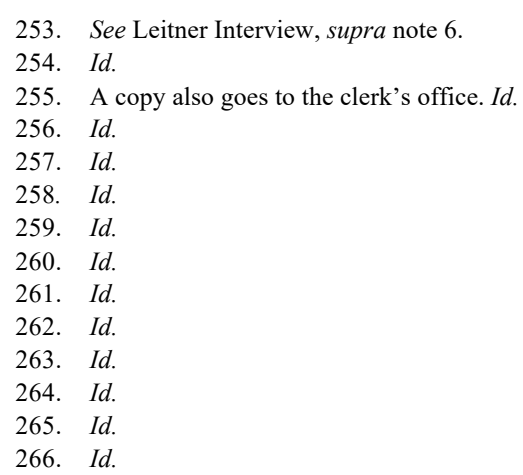


hotline. ${ }^{267}$ In addition, there are three secretaries who handle the paperwork. ${ }^{268}$ These eight employees work the daytime shift. ${ }^{269}$

Importantly, Harris County also fully staffs the intake division after traditional business hours have ended. ${ }^{270}$ Dozens of prosecutors from other parts of the office agree to work after-hours intake shifts in exchange for overtime pay. ${ }^{271}$ The first overtime shift runs from 5 p.m. to midnight, and the second intake shift runs from 12 a.m. to 8 a.m. ${ }^{272}$ Additionally, all weekend shifts are staffed by prosecutors working for overtime pay. ${ }^{273}$ The overtime pay is not a flat rate, but rather is based on a multiple of each prosecutor's base salary. ${ }^{274}$ Accordingly, more experienced senior prosecutors are paid more and have a strong financial incentive to work the overtime intake shifts. Because multiple prosecutors and staff are working intake shifts twenty-four hours a day, the system is expensive to operate. The 2014-2015 budget for the division was $\$ 6.2$ million. ${ }^{275}$

\section{B. Cost and Efficiency Savings Under the Harris County Model}

Although exact numbers are not available, it appears that Harris County intake prosecutors reject a considerable number of charges requested by police officers. In a 2006 study, researchers at Texas A\&M University interviewed "prosecutors and Houston police [and] conservatively estimate[d] the rate of early case rejection (i.e., while the defendant is still on the street) to be at least ten percent." 276 In reviewing the Harris County system, I spoke with current and former Harris County prosecutors, reviewed written declination files from the intake office, and observed an evening intake shift. ${ }^{277}$ Although anecdotal, all of those data points suggested to me that prosecutors reject charges with some frequency.

The type of charges Harris County prosecutors reject run the gamut. For example, in my review of charges that Harris County prosecutors rejected over the weekend of June 3-4, 2017, I saw two cases in which police officers from

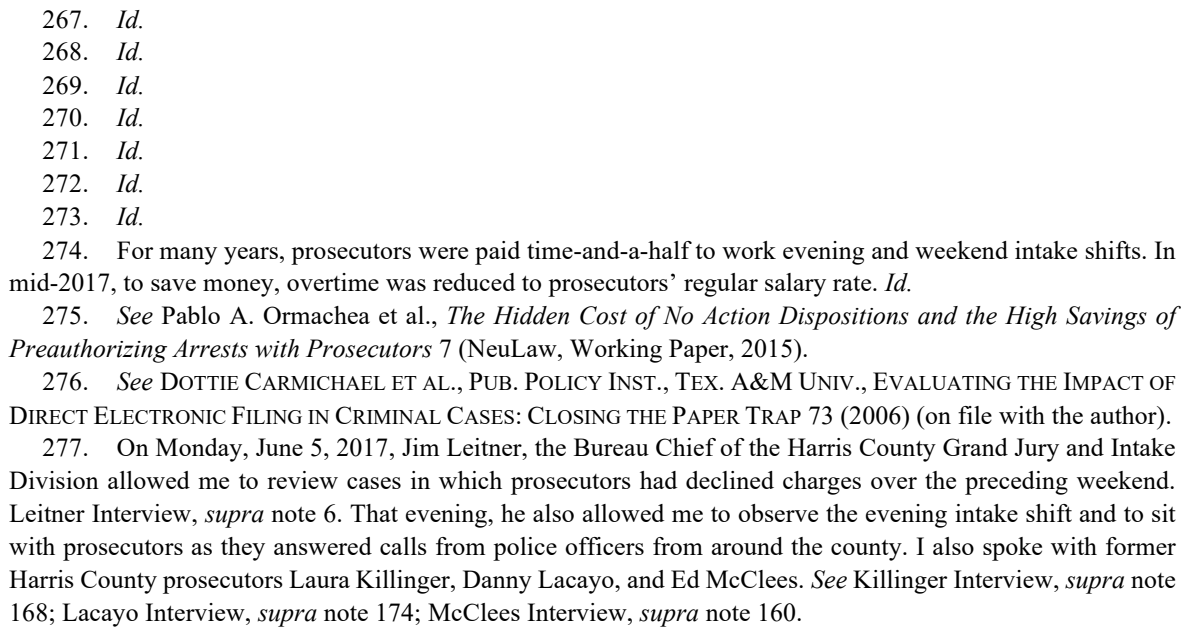


two different departments sought charges against suspects for being a felon in possession of a firearm. ${ }^{278}$ The police officers - certainly in good faith-looked at their databases and saw that these two defendants were on deferred adjudication for felony charges. ${ }^{279}$ However, because the officers did not have an intricate understanding of Texas law, they did not understand that deferred adjudication does not count as a conviction and thus those individuals were not felons for purposes of the felon in possession statute. ${ }^{280} \mathrm{In}$ short, it would be impossible to convict them because they could not be felons in possession under Texas law. ${ }^{281}$ Nevertheless, the police officers sought to arrest the two suspects and, in any other jurisdiction, the two individuals likely would have been incarcerated for days or longer, until a prosecutor looked at the case and dismissed the charges. ${ }^{282}$ Because the officers had to preclear the arrests with a Harris County intake prosecutor, however, the suspects were released at the scene. ${ }^{283}$

I observed written reports of other cases from the weekend of June 3-4 where prosecutors rejected charges because, unbeknownst to the police, it would be impossible to prove all the elements of the offense. ${ }^{284}$ For instance, a police officer tried to arrest a suspect for possession of a fraudulent credit card. ${ }^{285}$ The intake prosecutor however rejected the charge because the police officer did not have any evidence - as the statute requires - that the individual had tried to use the card. ${ }^{286}$ In another case, an officer tried to arrest a defendant for Class B theft, but the prosecutor rejected the charge because there was no evidence the property was worth more than $\$ 100$, as the statute requires to arrest a person for theft. ${ }^{287}$

Other cases where intake prosecutors rejected charges fall under the general heading of "contempt of cop." In one case from the weekend of June 3-4, officers sought charges for a "terroristic threat" because the suspect was threatening the officers with violence. ${ }^{288}$ The threat, however, was not "imminent" as required by the statute, and the intake prosecutor rejected the charge. ${ }^{289}$ In interviews, former prosecutors told me that police often try to charge suspects with the crimes of "evading arrest with a motor vehicle" or "resisting arrest" because the suspects did not pull over quickly or because they pulled their hands away while

\footnotetext{
278. Leitner Interview, supra note 6

279. Id.

280. See Ramon v. State, No. 13-15-00146-CR, 2016 WL $3364979 * 4-5$ (Tex. App. June 16, 2016).

281. After Jim Leitner of the Harris County District Attorney's Office explained this to me, it took me more than thirty minutes of legal research to find case law confirming it. If it takes a law professor with access to Westlaw that long, it is unlikely that the typical police officer will know it.

282. See supra text accompanying note 5.

283. See supra text accompanying note 6.

284. See supra note 277.

285. See supra note 277.

286. See Tex. Penal Code $§ 32.31$ (b) (West 2019).

287. Theft of less than $\$ 100$ is a Class $\mathrm{C}$ misdemeanor, which is punishable only by a fine. See TEX. PENAL CODE $§ 31.03$ (e) (West 2019); TEX. PENAL CODE $§ 12.23$ (West 2019).

288. See supra note 277.

289. See Tex. Penal Code $\S 22.07$ (a)(2) (West 2019).
} 
being handcuffed. ${ }^{290}$ These former prosecutors explained that intake prosecutors often reject these charges because proving the mens rea would be impossible. ${ }^{291}$

In other cases, Harris County prosecutors reject charges because police fail to understand that it will be difficult or impossible for prosecutors to prove the necessary mens rea to convict the suspect. For example, as noted above, ${ }^{292}$ former prosecutors explained that airport police officers often want to file charges when a passenger is found to have a weapon in his carry-on bag at airport security. ${ }^{293}$ Prosecutors, however, often reject those charges because the statute requires an intentional mens rea, rather than recklessness or negligence, and proving an intentional mens rea is very difficult. Indeed, while observing an intake shift on the evening of June 5, 2017, I witnessed a prosecutor reject charges for a suspect after a TSA agent found a large knife in his bag at the airport.

In other cases that I observed, prosecutors rejected what they considered unnecessary extra charges. In one example, officers sought two charges for evading arrest, but the prosecutor determined that all of the misconduct occurred in one transaction and thus filed only one count. In another case, police submitted multiple drug charges even though the defendant was in possession of only one drug. The prosecutor filed only one count. Indeed, I saw multiple instances in which prosecutors filed fewer drug charges than police requested. In one instance, police wanted to charge a defendant with .63 grams of cocaine and .04 grams of methamphetamine. The prosecutor accepted the former charge, but rejected the latter as unnecessary.

I also observed prosecutors repeatedly reject charges that would cause judicial backlogs. When police bring in both felony and misdemeanor charges, Harris County intake prosecutors often decline to file some of the misdemeanor charges out of judicial economy. For instance, I observed one intake call in which police stopped a woman for driving while intoxicated with a child in the vehicle. The officer also sought charges for drug possession, and a misdemeanor charge for unlawful possession of a firearm. The prosecutor declined the firearm charge because misdemeanor charges are processed in a different court and a defendant would be unlikely to plead guilty to a misdemeanor charge when she has pending felony charges in another court that have not been resolved. Rather than have a low-level case clog the docket in misdemeanor court, the prosecutor chose not to file the gun charge and proceeded only on the felony charges. This streamlining - which likely would not have happened in the absence of a prosecutor intake office - upsets some police officers, who may believe that suspects should be charged for all of the offenses they have plausibly committed. ${ }^{294}$

\footnotetext{
290. See supra notes $168-72$ and accompanying text.

291. Both the evading and resisting charges require the suspect to act intentionally. See TEX. PENAL CODE $\S \S 38.03(\mathrm{a}), 38.04(\mathrm{a})$ (West 2019).

292. See supra notes $181-86$ and accompanying text.

293. See Killinger Interview, supra note 168 ; McClees Interview, supra note 160 . The statutory provision is Tex. Penal Code $\S 46.03(5)$ (West 2019).

294. See Fairfax, supra note 187, at 1271.
} 
Intake prosecutors also decline to file charges as a matter of justice. For example, police officers are now frequently present in, or called to, public schools. ${ }^{295}$ When a fight breaks out between high school teenagers, the police sometimes want to charge one or both of the students. ${ }^{296}$ Prosecutors, however, sometimes decline to file those charges because they do not believe the teenagers should have a criminal record for a high school fight. ${ }^{297}$

These anecdotal examples indicate that Harris County prosecutors regularly screen out weak, inefficient, and unjust charges prior to arrest. ${ }^{298}$ Further evidence can be found in Harris County's low dismissal rate. A working paper by Pablo Ormachea and colleagues from the Center for Science and Law used a criminal records database to assess the number of "no action" dispositions and found the number in Harris County to be dramatically lower than in other jurisdictions. ${ }^{299}$ For instance, in 2011, Harris County dropped 1,177 charges, compared with 35,030 in Miami-Dade County. ${ }^{300}$

The benefits of the Harris County intake system are not limited to rejecting charges. Having a prosecutor work with a police officer at the time of arrest strengthens cases that will be filed. For instance, while observing the intake shift on June 5, 2017, I observed the chief of the intake division-who has three decades of experience as a prosecutor and defense attorney - explain to an officer that he needed additional information in order to successfully prosecute a suspect for possession of marijuana in a drug-free school zone. In his report, the officer had failed to identify the name and location of the school as required by the statute. ${ }^{301}$ If the prosecutor had not instructed the officer to correct this omission immediately, it is possible that weeks later when the problem was discovered that the officer might not have remembered the location and the case would have to be dismissed. A similar problem occurs when police seek charges for theft of a firearm. The officers do not always understand that finding a defendant in possession of a seemingly stolen firearm is not sufficient. Prosecutors must prove the firearm has been taken from its owner, and thus the charging documents must specify the name of the owner. ${ }^{302}$

Prosecutor involvement at the arrest stage also allows for a more careful look at bond amounts and helps to keep dangerous individuals off the street. In many states, including Texas, the Penal Code sets forth a complicated scheme of

295. See Jason P. Nance, Students, Police, and the School-to-Prison Pipeline, 93 WASH U. L. REv. 919, 922 (2016).

296. See Kristin Henning, Criminalizing Normal Adolescent Behavior in Communities of Color: The Role of Prosecutors in Juvenile Justice Reform, 98 CORNELL L. REV. 383, 386 (2013).

297. See id. at 386-87 (noting racial disparities in charging, and advocating for greater declination of charges).

298. Harris County also has a system in place to make sure rejected cases were handled correctly. The Division Chief reviews every rejected case within a day of the rejection. Therefore, if a case was wrongly rejected, prosecutors can quickly move to charge the defendant.

299. See Ormachea et al., supra note 275 , at 2-3.

300. Id. at 4 .

301. See Tex. Health \& SAFETy Code $\$ 481.134$ (West 2019).

302. See TeX. Penal Code $\S 31.03(\mathrm{e})(4)(\mathrm{C})$ (West 2019); Leitner Interview, supra note 6. 
charging enhancements. ${ }^{303}$ In one case I observed during the June 5, 2017, intake shift, police sought a charge that would typically have carried a $\$ 1,000$ bond under the bond schedule. When the intake prosecutor looked carefully at the defendant's criminal history, though, he was able to deconstruct the long rap sheet and determine that the defendant had two prior serious felony convictions with time spent in the state penitentiary. At the moment of arrest, the prosecutor therefore was able to make a recommendation that the defendant be treated as a habitual offender and the suspect be denied bond. A magistrate judge might have made the same discovery from reviewing the defendant's criminal history, but not necessarily.

In sum, by prescreening warrantless arrests, Harris County prosecutors are able to prevent flawed cases from being filed, reduce the number of charges to prevent clogs in the system, and screen out charges that while technically appropriate might be unjust. At the same time, prosecutors are able to strengthen cases that will be filed by having police acquire key information immediately rather than scrambling for it days or weeks after charges are filed. 


\section{Replicating the Harris County Approach in El Paso and Montgomery Counties}

One objection to the Harris County system of prosecutorial prescreening of warrantless arrests is that it is labor intensive and expensive. Harris County is the third largest county in the country and therefore has a substantial budget and a large enough number of employees to have some prosecutors work in its intake division. ${ }^{304}$ By contrast, smaller jurisdictions have less money and smaller staffs and would thus find it difficult to fund an intake division. This concern is obviously logical. Nevertheless, the Harris County approach has been replicated in the far smaller El Paso and Montgomery counties in Texas. Moreover, those counties have discovered that they are actually saving money by using the Harris County approach.

\section{El Paso Recognized the Cost and Efficiency Savings Two Decades Ago}

In 1994, El Paso County, Texas-which has a population six times smaller than Harris County ${ }^{305}$ - decided to replicate the Harris County intake system. Prosecutors began to screen warrantless arrests twenty-four hours a day. ${ }^{306} \mathrm{Be}-$ cause El Paso is a much smaller jurisdiction, it only has one prosecutor work the intake shift at a time, rather than the three or four prosecutors working simultaneously in Harris County. ${ }^{307}$ The El Paso police (a city agency) and the prosecutor's office (a county department) reached a formal financial arrangement and drew up an interlocal governmental agreement to distribute the costs of the system. ${ }^{308}$ City and county officials have supported the program for over twenty years because they believe it ultimately saves money by (1) reducing the number of people incarcerated; (2) reducing the time of each defendant's pretrial incarceration; and (3) reducing time spent on cases by prosecutors, defense attorneys, and courts. ${ }^{309}$

A 2006 study by researchers at Texas A\&M University offered dramatic documentation of the financial savings that come when prosecutors prescreen arrests and file charges electronically from their office. ${ }^{310}$ Researchers compared misdemeanor cases disposed of in calendar year 2004 in Harris, El Paso, and Bexar counties in Texas. ${ }^{311}$ In Harris County, all of the cases were screened by

304. Adam M. Gershowitz, The Intake Prosecutor: Prosecutorial Screening Before the Police Make Warrantless Arrests 30 (William \& Mary Law School, Research Paper No. 09-362), http://ssrn.com/abstract $=3037172$.

305. See U.S. Census Bureau, QuiCK FACTS, El PASO COUNTY, TEXAS, https://www.census.gov/quickfacts/fact/table/elpasocountytexas/PST045216 (last visited Mar. 28, 2019).

306. See Telephone Interview with Claudia Duran, Project Manager, El Paso County District Attorney's Office (June 8, 2017) [hereinafter Duran Interview].

307. See id

308. The agreement is re-authorized each year. See, e.g., INTERLOCAL GOVERNMENTAL AgREEMENT (2016) (on file with the author).

309. See Duran Interview, supra note 306.

310. See generally CARMICHAEL ET AL., supra note 276.

311. Id. at $2-3$. 
prosecutors at the moment of arrest. ${ }^{312}$ In Bexar County, none were screened. ${ }^{313}$ In El Paso (in 2004), the cases handled by the El Paso Police Department - about two-thirds of the total-were screened by prosecutors at the moment of arrest, while the cases handled by the El Paso Sheriff's Office were not screened by prosecutors. ${ }^{314}$

The researchers found that El Paso prosecutors rejected 19\% of the cases that city police officers brought in. ${ }^{315}$ In total, El Paso prosecutors rejected thousands of misdemeanor cases where police sought charges. ${ }^{316}$ From a financial standpoint, the study found that if El Paso moved to a system in which prosecutors screened all misdemeanor cases, it would save the county approximately $\$ 1.5$ million in costs associated with transportation, jailing, offense report submission, magistrate appearances, and appointed counsel. ${ }^{317}$ It also would save the prospective defendants an estimated $\$ 1.23$ million that they would have spent on bond, retained counsel, and lost wages had they been incarcerated. ${ }^{318}$ And, of course, this would be just the savings in misdemeanor cases.

Although there was not comparable data for Harris County, the researchers reported that "prosecutors and Houston police interviewed conservatively estimate the rate of early case rejection (i.e., while the defendant is still on the street) to be at least ten percent." ${ }^{319}$ Given that Houston handles roughly five times as many cases as El Paso, ${ }^{320}$ the savings to Harris County and its defendants are likely dramatically greater than those outlined above for El Paso.

Additionally, because prosecutors in Harris County and El Paso County screened the cases at the moment of arrest and could electronically file the documents themselves without waiting for paperwork to be sent over from the police, cases that did result in arrest were processed far faster. ${ }^{321}$ In Harris County (where all cases go through the intake office), 25\% of misdemeanor cases were disposed of within three days of arrest; in El Paso (where, at the time, two-thirds of misdemeanor cases were screened by prosecutors) $15 \%$ of cases were disposed of in three days. ${ }^{322}$ By contrast, in Bexar County, which does not have prosecutors screen any cases, $0 \%$ of the cases were resolved in three days. ${ }^{323}$ This data indicates that by having prosecutors screen cases and file charges electronically

\footnotetext{
312. See id. at $18-19,39$.

313. See id. at $33-37,39$.

314. See id. at 25-32, 39. In recent years, El Paso has moved to prosecutorial prescreening of all misdemeanor cases. See E-mail from Claudia Duran, Project Manager, El Paso County District Attorney's Office, to author (June 8, 2017).

315. See CARMichael et AL., supra note 276, at 73.

316. See Direct Electronic Filing in Criminal Cases: Closing the Paper Trap, task Force ON INDIGENT DEFENSE 21, http://www.tidc.texas.gov/media/34550/070424_ClosingPaper_Presentation _ FINAL.pdf.

317. See id. at 19-21.

318. See id.

319. CARMICHAEL ET AL., supra note 276, at 73 .

320. See id. at $17,23$.

321. Id. at 74 .

322. See id.

323. See id.
} 
(rather than waiting for police to forward their reports days or weeks later) the strongest cases are resolved quickly with many defendants pleading guilty in the first few days after arrest. These fast dispositions mean the counties spend less money on jail costs and defendants save money by extricating themselves from the system and getting back to their jobs. Researchers estimated that the faster case processing that comes with prosecutorial screening and electronic filing could save El Paso County $\$ 3.95$ million and save defendants $\$ 3.26$ million. ${ }^{324}$ And, once again, this is just in misdemeanor cases.

In sum, the researchers concluded that other jurisdictions should adopt twenty-four hour prosecutorial screening of warrantless arrests. ${ }^{325}$ The benefits included: a reduction (by up to $20 \%$ ) in the number of charges, prompt disposition of charges that are filed, less paperwork for police, and more accurate charging decisions. ${ }^{326}$ Additionally, the researchers found that counties employing the Harris County model would save money because of reduced jail admissions, reduced inmate transportation costs, fewer court-appointed assignments, and less prosecutorial time spent on cases later in the process. ${ }^{327}$ They also recognized that " $[\mathrm{w}]$ here cases are screened out at arrest, defendants are spared the costs of private attorney fees, bond fees, lost wages, and family disruption in a case that would have ultimately been rejected by the prosecutor." ${ }^{, 328}$

\section{Montgomery County Adopted a Similar System a Decade Ago}

Montgomery County, Texas - a medium sized county of slightly more than 500,000 people - is directly north of Houston and occasionally hires former Harris County prosecutors. ${ }^{329}$ In 2008, likely influenced by its southern neighbor, Montgomery County established its own intake system for prosecutors to screen warrantless arrests. ${ }^{330}$ Because it is a smaller office, Montgomery's process is slightly different than that in Harris and El Paso. ${ }^{331}$ The core goal howeverhaving prosecutors assist police with warrantless arrests and carefully vet charges - is identical. ${ }^{332}$

In Montgomery County, a rotating prosecutor is assigned to the jail twentyfour hours per day to guide officers on charges and offer advice on evidence collection. ${ }^{333}$ Police either call the intake hotline or come in person to present

\footnotetext{
324. See Direct Electronic Filing in Criminal CASES: Closing the Paper Trap, supra note 316, at

325. See CARMichael ET AL., supra note 276, at 103-04.

326. See id.

327. See id. at 105 .

328. Id.

329. The description of the Montgomery County system is based on an interview I conducted with Montgomery County prosecutors Mike Holley, First Assistant District Attorney, and Darla Faulkner, the chief prosecutor in the Intake Division, on June 8, 2017. Interview with Mike Holley, First Assistant Dist. Attorney \& Darla Faulkner, Chief Prosecutor, Intake Div., Montgomery County Prosecutor's Office (June 8, 2017).

330. Id.

331. Id.

332. Id.

333. Id.
} 33. 
possible charges. ${ }^{334}$ The prosecutor then accepts the charges, modifies the officer's proposed charges, or rejects the charges altogether. ${ }^{335}$

The Montgomery County system actually began with prosecutors volunteering their time after hours because they saw the value in improving evidence collection and weeding out weak charges early in the process. ${ }^{336}$ Later, the system became more formalized. Because it is smaller than Harris County, the Montgomery County intake process uses fewer prosecutors and staff members. A rotating prosecutor is assigned to the intake office during business hours and a different, permanent prosecutor works the midnight to 8:00 a.m. shift. ${ }^{337} \mathrm{Be}-$ tween 5 p.m. and midnight and on weekends, prosecutors from other parts of the office work the intake shift for overtime pay. ${ }^{338}$

Prosecutors in Montgomery County explained that the intake system pays for itself in a variety of ways. First, prosecutors are able to find the appropriate charges very early, rather than having to do that work later. Second, in cases where there is a victim - particularly family violence cases - prosecutors are able to move quickly to both protect the victim and to encourage her to cooperate with the prosecution rather than being convinced by the suspect to recant. Third, early involvement in the case enables prosecutors to have input on the bond amount, sometimes encouraging the judge to increase the amount to protect the community and other times suggesting a lower amount to remove less dangerous individuals from pretrial detention.

\section{Expanding Prosecutorial Pre-Screening of WARrantless ArRests TO OTHER COUNTIES}

The Harris County experience demonstrates that it is possible for a large prosecutor's office to screen all warrantless arrests before police take suspects into custody. The experience in El Paso County (with a population of 660,000) and Montgomery County (with a population of 500,000) shows that it is feasible for prosecutors in medium-sized counties to prescreen all warrantless arrests. ${ }^{339}$ Of course, implementing prosecutorial screening requires a considerable investment in up-front personnel costs. Large and medium-sized counties would have to hire one or more prosecutors (depending on the size of the office) to work the day shifts, and they would have to pay overtime for the evening and weekend shifts. ${ }^{340}$ But the cost savings in the long run from rejecting weak cases that would be later dismissed (as well as the other efficiencies described in Section III.B) would seemingly more than offset the personnel costs. Indeed, the Texas

\footnotetext{
334. Id.

335. Unlike Harris County, it is possible for law enforcement officers in Montgomery County to jail a suspect prior to asking prosecutors to accept charges. Supervising prosecutors said that this happens extremely rarely however. See id.

336. Id.

337. Id.

338. Id.

339. See supra Subsections III.C.1, III.C.2.

340. See supra notes $270-75$ and accompanying text.
} 
A\&M study comparing prosecutors' offices that have intake offices with a county that does not screen cases demonstrated millions of dollars in potential savings to the counties and the defendants. ${ }^{341}$ As such, the simple policy prescription of this Article is that large and medium-sized counties should follow the Harris County approach and have prosecutors prescreen all warrantless arrests.

A remaining question is whether prosecutorial screening of warrantless arrests can be implemented in small counties. While large and medium-sized prosecutor's offices handle a majority of the criminal cases in the United States, ${ }^{342}$ it is nevertheless the case that most prosecutors' offices in the United States are relatively small. ${ }^{343}$ Over $70 \%$ of prosecutor's offices serve districts with populations of less than 100,000 people. ${ }^{344}$ And in those small districts, the average office has only four prosecutors. ${ }^{345}$ It simply would not be feasible for such leanly staffed offices to screen cases around the clock.

A partial solution would be for states to fund intake prosecutors who can be shared by small counties. ${ }^{346}$ Prosecutors in a state office would answer calls from police around the state and approve, reject, or modify charges prior to warrantless arrests. If police seek to bring an obviously meritless case, or if they seek felony charges when only a misdemeanor prosecution would be appropriate, the state intake prosecutor would reject those charges, at least for the time being. ${ }^{347}$

The case for state involvement is straightforward. First, with the exception of a small number of municipal offenses, state law sets forth criminal liability. ${ }^{348}$ As such, state prosecutors are just as well situated as local prosecutors to determine whether a suspect's conduct met the elements set forth in the state penal code. ${ }^{349}$ Second, because existing intake systems screen charges by phone, there is no need for the intake prosecutor to be in the same county as the police officer and the suspect. Third, while criminal prosecutions are mostly local in the United States, the decision to input a case into the criminal justice system affects numerous entities outside of the locality. Public defenders and courts must use their state funding to deal with charges filed by police. ${ }^{350}$ Arrestees are often housed

341. See supra notes 332-33 and accompanying text

342. See Steven W. Perry \& Duren Banks, Bureau of Justice Statistics, U.S. Dep't of Justice, NCJ234211, Prosecutors in State Courts, 2007-Statistical TABles 5 tbl.4 (2011).

343. See id. at 4 tbl.2.

344. Id. at 2 .

345. See id.

346. If a local prosecutor's office already has its own intake department, it would not need to make use of the state office.

347. If police believe that the state intake prosecutor incorrectly rejected charges, they could always approach their local prosecutor's office and seek to have the local prosecutor pursue an arrest warrant. In this way, ultimate prosecutorial control would continue to rest with local prosecutors.

348. Logan, supra note 158, at 99; see also Stuntz, supra note 16, at 515.

349. Enforcement priorities - such as not dropping domestic violence charges or deciding to downgrade possession of a trace amount of a controlled substance to possession of drug paraphernalia - would remain in the hands of local prosecutors.

350. In some jurisdictions, however, public defender funding falls to the counties. See Cara H. Drinan, The Third Generation of Indigent Defense Litigation, 33 N.Y.U. REV. L \& Soc. Change 427, 458-59 (2009). 
in regional jails that handle inmates from multiple counties. ${ }^{351}$ States supervise those jails and the state attorney general's office must deal with lawsuits about confinement conditions. ${ }^{352}$ Moreover, many local district attorneys' offices already receive state funds to supplement their local budgets. ${ }^{353}$ In short, while criminal prosecutions are local — and will certainly remain that way ${ }^{354}$ — there are systemic reasons for states to allot funds to weed out weak cases early in the process.

Having state prosecutors answer an intake line would not threaten local control of charging decisions. If a state intake prosecutor were to reject a case, that would not bar further review by the local prosecutor. Police could still bring the case to the local prosecutor during normal business hours, and if the local prosecutor believed the case was strong enough, she could ask a magistrate to issue an arrest warrant. The state intake prosecutor would therefore only serve as a temporary speed bump for the weakest warrantless arrests.

In the alternative, if the idea of a centralized state intake prosecutor is too radical, states could take a more modest step by simply providing grant funding to counties to hire their own local intake prosecutors. A number of prosecutor's offices I spoke with suggested they would be interested in state funds to hire their own intake prosecutors. ${ }^{355}$

\section{CONCLUSION}

For many years, criminal justice reformers have paid close attention to excessively long sentences. ${ }^{356}$ Recently, reform efforts have focused on an earlier

351. See Jennifer Feehan, Prosecutor Calls for Help to Keep Regional Jail Open, ToLEDo BLADE (Nov. 21, 2015), https://www.toledoblade.com/local/2015/11/21/Prosecutor-calls-for-help-to-keep-regional-jail-open/stories/feed/index.rss (noting dispute over Toledo's failure to pay its share of costs).

352. There are also indirect costs. When suspects are needlessly arrested and cannot make bail, they often lose their jobs while incarcerated. They may then turn to state public assistance programs to help them get back on their feet. See Tami Luhby, Unemployment Benefits Cost: \$520 Billion, CNN: BusINESS (Nov. 12, 2012, 1:46 PM), https://money.cnn.com/2012/11/29/news/economy/unemployment-benefits-cost/index.html.

353. See Carol DeFrances, U.S. Dep't of Justice Bureau of Justice Statistics, NCJ193441 PROSECUTORS IN STATE COURTS, 20014 (2002) (noting that about half of prosecutor's offices surveyed reported receiving some funding from state sources).

354. I have argued for eliminating local control of capital punishment. See Adam M. Gershowitz, Statewide Capital Punishment: The Case for Eliminating Counties' Role in the Death Penalty, 63 VAND. L. REV. 307,359 (2010). Faith in local control is so strong however that even that proposal met with serious objection. See Stephen F. Smith, Localism and Capital Punishment, 64 VAND. L. REV. EN BANC 105, 120-21 (2011).

355. Most offices indicated that they would not be interested in a statewide call line, but would be interested in state funding. See, e.g., E-mail from Wesley Wittig, supra note 83 ("Hard to turn down funding, but ... [w] are not interested in a statewide call line-we are positioned to make the best decisions for our community here.").

356. For instance, Families Against Mandatory Minimums has been lobbying for shorter sentences since 1991. FAMM's History, FAMM, http://famm.org/about/famms-history/ (last visited Mar. 28, 2019). 
part of the criminal justice system and sought to eliminate over-charging by prosecutors ${ }^{357}$ and the practice of cash bail. ${ }^{358}$ While those are all worthy efforts, this Article suggests an even earlier intervention point.

Almost all counties in the United States put initial arrest decisions in the hands of police, not prosecutors. ${ }^{359}$ In some large counties, prosecutors then step into the process within twelve hours. ${ }^{360}$ More commonly, prosecutors do not have a role until the probable cause hearing, which can be as late as forty-eight hours after arrest. ${ }^{361}$ And in some jurisdictions, prosecutors do not have any role until even later in the process, leaving suspects locked up for weeks before a prosecutor looks at the case. ${ }^{362}$

In almost all jurisdictions, it is the police, not the prosecutor, who trigger a cascade of effects for arrestees. ${ }^{363}$ Warrantless arrests trigger a need to post bail; an increased deportation risk; the prospect of losing a job; public housing problems; and, particularly in misdemeanor cases, considerable pressure to plead guilty. Warrantless arrests also create work for jailers, clerks, judges, prosecutors, and public defenders.

The cascade of consequences triggered by warrantless arrests would not be concerning if we had confidence the police were not over-arresting and were filing the right set of charges. Yet strong evidence indicates reason for alarm. For decades, prosecutors across the country have dismissed $25 \%$ of the felony cases filed by police. ${ }^{364}$ There is no good data on the dismissal rates for misdemeanor cases, although basic common sense suggests dismissals are common when lower-stakes cases are involved. High dismissal rates tell us that the hands-off approach taken by most prosecutors is not only inefficient for the key players in the system but also unfair to the enormous number of arrestees who must suffer through the criminal justice process only to see the State later conclude there is no basis to proceed with their cases. ${ }^{365}$

A few jurisdictions have found a better way. In Harris County, Texas - and at least two medium-sized counties that have followed suit—-prosecutors screen all warrantless arrests. ${ }^{366}$ No one is taken to jail without a prosecutor first reviewing the case. ${ }^{367}$ And prosecutors regularly reject charges while the potential arrestee is still on the street. ${ }^{368}$ The result is that suspects are released immediately

357. See, e.g., Conor Friedersdorf, 8 Ways to Stop Overzealous Prosecutors from Destroying Lives, ATLANTIC (Jan. 21, 2013), https://www.theatlantic.com/politics/archive/2013/01/8-ways-to-stop-overzealousprosecutors-from-destroying-lives/267360/.

358. Recent litigation in Harris County, Texas has targeted the cash bail system for poor defendants charged with low-level misdemeanors. See Rosenberg, supra note 208.

359. See supra note 5 and accompanying text.

360. See supra notes 53-60 and accompanying text.

361. See supra notes 32-41 and accompanying text.

362. See supra notes 222-26 and accompanying text.

363. See supra notes 9-11 and accompanying text.

364. See supra note 4 and accompanying text.

365. See Malcolm M. Feeley, The Process Is the Punishment 266 (1979).

366. See supra Subsections III.C.1, III.C.2.

367. See supra note 312 and accompanying text.

368. See supra note 319 and accompanying text. 
rather than being left to languish for days, weeks, or months before their cases are dismissed.

The Harris County system involves considerable up-front costs because at least one prosecutor must be on duty twenty-four hours a day to review calls from police. ${ }^{369}$ The system is nevertheless logistically and financially feasible. Many prosecutor's offices already have hotlines in place for police to ask prosecutors questions. ${ }^{370}$ Calls to these hotlines would simply become mandatory rather than optional. And while the costs of staffing prosecutors twenty-four hours a day would be considerable, counties would recoup the costs (and likely even see overall costs decline) by saving money on jail admissions, transportation of inmates, unnecessary police reports, court costs, and public defender involvement, to name just a few. In short, counties have the opportunity to simultaneously reduce harm to arrestees and limit the workload of numerous criminal justice actors by having prosecutors pre-screen warrantless arrests.

369. See supra note 304 and accompanying text.

370. See supra note 10 and accompanying text. 